\title{
Capital Requirements, Business Loans, and Business Cycles: An Empirical Analysis of the Standardized Approach in the New Basel Capital Accord
}

\author{
Seth B. Carpenter, William Whitesell, and Egon Zakrajšek \\ Board of Governors of the Federal Reserve System
}

November 13, 2001

\begin{abstract}
In the current regulatory framework, capital requirements are based on riskweighted assets, but all business loans carry a uniform risk weight, irrespective of variations in credit risk. The proposed new Capital Accord of the Bank for International Settlements provides for a greater sensitivity of capital requirements to credit risk, raising the question of whether, and to what extent, the new capital standards will intensify business cycles. In this paper, we evaluate the potential cyclical effects of the "standardized approach" to risk evaluation in the new Accord, which involves the ratings of external agencies. We combine Moody's data on changes in U.S. borrowers' credit ratings since 1970 with estimates of the risk profile of business loans at commercial banks from the Survey of Terms of Business Lending, and also a risk profile estimated by Treacy and Carey (1998). We find that the level of required capital against business loans would be noticeably lower under the new Accord compared with the current regime. We do not find evidence of any substantial additional cyclicality in required capital levels under the standardized approach of the new Accord relative to the current regime.
\end{abstract}

* Division of Monetary Affairs. We thank Thomas Brady, Mark Carey, William English, Myron Kwast, David Lindsey, Brian Madigan, and William Nelson for helpful comments, and Renee Johnson for excellent research assistance. The views expressed in this paper are solely the responsibility of the authors and should not be interpreted as reflecting the views of the Board of Governors of the Federal Reserve System or of any other person associated with the Federal Reserve System. Please address all correspondence to: The Board of Governors of the Federal Reserve System, $20^{\text {th }}$ Street and Constitution Avenue NW, Washington D.C. 20551. Email: seth.carpenter@frb.gov, william.whitesell@frb.gov, egon.zakrajsek@frb.gov . 


\section{Introduction}

The proposed new Basel Capital Accord (Bank for International Settlements, 2001) provides for a greater sensitivity of capital requirements to the credit risk inherent in bank loan portfolios. This heightened sensitivity raises the question of whether, and to what extent, the new capital standards will intensify business cycles. The potential procyclicality of capital standards has been studied by numerous researchers, including Blum and Hellwig (1995), Heid (2000), Altman and Saunders (2001), and Borio, Furfine, and Lowe (2001). This paper is intended to provide some empirical estimates of the potential magnitude of the cyclical effects of the new Accord relative to the existing regime implemented following the Basel Accord of 1988.

The credit supply behavior of banks may affect the cyclicality of economic activity for a variety of reasons, including factors that are unrelated to capital requirements, such as time-varying perceptions of and aversions to risk among loan officers. In addition, erosion of banks' economic capital due to losses may reduce the supply of new loans even in the absence of capital regulation. Regulation, however, may at times make capital constraints more binding. High capital adequacy ratios, with stricter enforcement than markets themselves might impose, could induce cyclicality into loan supply to the extent that the ratios become binding during business downturns. A regulatory regime may thus have cyclical effects because of the level of capital it requires, as well as the sensitivity of required capital to changes in risk over the business cycle.

Under the current regulatory regime, the level of required capital is based on riskweighted assets, and all commercial and industrial (C\&I) loans carry a risk weight of 100 
percent, irrespective of variations in credit risk across loans and across time for the same loan. Under the proposed new Accord, C\&I and other loans will be allocated among risk classes, each of which carries its own risk weight. A loan that becomes riskier, because of a deterioration in the credit quality of the borrower, could be shifted into a risk class that would require a greater amount of capital. If the general economic climate deteriorated sufficiently, a number of loans might have to be reallocated to a higher riskweight category, and capital requirements could rise noticeably. As a result, banks may need to raise capital or shed risk-weighted assets to avoid regulatory actions. Because issuing new equity may be difficult in the short-run, banks may shift assets away from higher-risk loan categories (Haubrich and Wachtel (1993)) or reduce the growth of their overall balance sheets (Bernanke and Lown (1991)). In consequence, credit supply conditions might become more restrictive as an economy is falling into recession under the new capital regime than under the existing one.

To tie capital requirements more closely to the underlying risk in bank loan portfolios, the new Accord allows for two main approaches to evaluating the credit risk inherent in individual loans. Banks with sufficiently developed risk assessment systems may use an internal-ratings-based method to estimate the credit risk of their loan portfolios. The lack of historical data makes it difficult to evaluate empirically the potential cyclical effects of such an approach.

The new Accord, however, allows any bank to use a "standardized approach" to risk assessment, which involves evaluating corporate loans by employing the ratings on

\footnotetext{
${ }^{1}$ For a general equilibrium quantitative assessment of the effects of credit supplies on the business cycle, see Bernanke, Gertler, and Gilchrist. (1999). Gertler and Gilchrist (1993) provide an empirical assessment of the lending channel of monetary transmission for the United States and Kashyap and Stein (1997) for the Euro area.
} 
unsecured debt issues provided by external agencies such as Moody's, Standard and Poor's, and Fitch. Under this approach, loans to corporations would be allocated among four risk categories: a risk weight of 20 percent would be assigned for claims rated Aaa or $\mathrm{Aa}, 50$ percent for A-rated claims, 100 percent for Baa or Ba ratings, and 150 percent for claims rated B or below. Unrated claims against corporations would receive a risk weight of 100 percent.

In this paper, we present estimates of how such risk-weighted C\&I loans might have evolved over the last three decades if banks had been using the standardized approach of the new Accord. We employed data on changes in credit ratings from Moody's Investors Services to capture variation in borrower credit quality over time. As a proxy for the starting risk distribution of C\&I loans in the portfolio of a representative bank, we used data from the Federal Reserve's quarterly Survey of the Terms of Business Lending (STBL), as well as a risk distribution obtained in a separate survey undertaken in late 1997 by Treacy and Carey (1998).

After describing the data and our methodological adjustments, we examine what empirical evidence can be gleaned regarding possible cyclical effects of the proposed new Accord relative to the existing capital regime. Our counterfactual historical analysis suggests that the variation in ratings over the business cycle would not have been substantial enough to imply much additional cyclical movement in risk-weighted C\&I loans under the standardized approach of the new Accord. However, our results imply that, relative to the current regime, the average level of capital required against C\&I loans

\footnotetext{
${ }^{2}$ We use Moody's rating notations throughout the paper. The BIS Committee on Banking Supervision (2001) uses Standard and Poor's, but only as an example. Given the broad rating categories used, each of these notation conventions can be mapped into the other.
} 
would likely be noticeably lower for banks using the standardized approach of the new Accord.

\section{External Ratings Data}

Borrower credit ratings were obtained from Moody's Credit Risk Management Services database on the senior unsecured debt of rated firms, which is available beginning in 1970. For firms without a rating on senior unsecured debt, but with other rated debt, Moody's has imputed a senior unsecured rating. Moody's ratings, like those for other external agencies, are based on a borrower's ability to meet its debt obligations in the event of an economic downturn and do not correspond to a default probability over a specific time horizon; see, for example, Cantor (2001). While that rating philosophy may create a presumption against changes in ratings over the business cycle, the additional information available during actual downturns nevertheless might be thought likely to induce some cyclical effects.

We restricted our sample to domestic, nonfinancial issuers; the number of such issuers with Moody's ratings rose from around 1,000 in 1970 to over 2,200 by the end of 2000, as shown in the top panel of Exhibit 1. (All tables and exhibits are presented at the end of the paper.) The bottom panel of Exhibit 1 plots, as of the beginning of each quarter, the fraction of such issuers belonging to the four risk-weight categories that will be used in the standardized approach of the new Accord. It is an extended and more granulated version of a chart shown in Altman and Saunders (2001). The 100 percent risk-weight category (firms rated $\mathrm{Baa}$ to $\mathrm{Ba}$ ) represented the largest group over almost all of the period. The share of firms in the 150 percent risk-weight category has risen 
substantially over the last two decades, reflecting the development of the junk bond market.

The shaded regions in the chart depict NBER-dated recessions. No cyclical pattern in the behavior of the shares of firms in the different categories is immediately evident. The chart reveals a noticeable shift out of the 100 percent risk-weight category and into the 150 percent category in late 1999. Conversations with Moody's officials indicated that this pattern was attributable to the effects of the deteriorating position of sovereign debtors, following the financial turmoil in late 1998. While sovereign issuers are not included in our sample, Moody's reportedly re-examined the position of corporate borrowers with business operations in the affected countries over 1999 and downgraded their debt in a number of cases. An even larger shift among rating categories occurred in 1982, coinciding with Moody's introduction of refined grades (for example, A1, A2, and A3 instead of just A). At this time there was apparently a readjustment of basic rating assignments for a number of firms.

Aside from issuer ratings themselves, Moody's database service also facilitates construction of transition matrices of firms across rating categories over periods of any specified length. Each column of a transition matrix is associated with a given initial rating. The elements of the column show the fraction of issuers with that initial rating that ended the period in each of the possible rating categories. Using this tool, we computed quarter-to-quarter transition matrices of issuer ratings from 1970 through 2000 and then condensed the ratings into the four risk categories of the new Basel Accord.

The transition matrix for each quarter was constructed by excluding firms that withdrew as rated issuers during that quarter. An analysis undertaken by Carty (1997) 
revealed that around 90 percent of withdrawals occurred because the underlying securities matured or were called, rather than because of any deterioration of credit quality. Thus, by excluding these issuers, we were unlikely to have induced much selection bias into the rating transition matrices.

Ideally, we would like to use rating transition matrices in which each issuer is weighted by the stock of its outstanding debt, rather than one based on the number of issuers. Unfortunately, Moody's database does not readily lend itself to construction of such value-weighted transition matrices, because the data do not contain information on borrowers' outstanding debt at a point in time. However, differences in the initial amount of debt outstanding across risk classes have no affect on the transition matrices. Also, within a risk category, if the probability of a rating change was independent of the amount of an issuer's outstanding debt, then transition matrices based on the number of issuers would be equivalent to value-weighted transition matrices in large samples. The development of value-weighted transition matrices is a subject for future research.

The average of the quarterly transition matrices over the period from 1970:Q1 to 2000:Q4 is shown in Table 1. As indicated by the numbers close to unity along the principal diagonal, most borrowers, on average, remained in the same risk-weight category from one quarter to the next. However, about 1-1/2 percent, on average, of the firms in each of the 20 percent and 50 percent risk-weight categories were downgraded one category over a quarter. About 2-1/2 percent of firms in the 150 percent risk-weight category defaulted on their obligations over an average quarter, while 1-3/4 percent were upgraded to the next category. 
The capital effect of these migrations is worth noting. Shifts between the 20 percent and 50 percent risk-weight categories have the largest percentage effects on required capital under the new Accord: A downgrading from the 20 percent category to the 50 percent category would imply a percentage increase in required capital against that loan equal to the percentage rise in the risk-weighted loan amount, which is (50-20)/20, or 150 percent. Methods for handling transitions into default will be discussed in subsequent sections. Of course, actual bank capital would be directly impaired by defaults, although the size of the hit to capital would likely depend on provisioning and charge-off policies, rather than capital requirements.

\section{Data on Business Loan Profiles}

In recent years, internal credit ratings have become increasingly important in credit risk management at both foreign and U.S. commercial banks. We exploit two sources of data on internal risk ratings — a study of large U.S. banks by Treacy and Carey (1998) and the Survey of Terms of Business Lending (STBL), conducted quarterly by the Federal Reserve.

Treacy and Carey (1998) reviewed internal reports containing distributions of rated loans at commercial bank subsidiaries of the fifty largest domestic bank holding companies (BHCs). For twenty-six BHCs-accounting for more than 75 percent of aggregate banking industry assets at year-end 1997-they obtained mappings of internal grades to the equivalent grades of external rating agencies. The resulting risk profiles were kindly provided to us by Mark Carey. We condensed these profiles into the risk- 
weight categories corresponding to the standardized approach of the proposed new

Accord and used the result as one proxy for an initial allocation of bank business loans.

The STBL uses a stratified sample of large and small domestic banks and U.S.

branches and agencies of foreign banks to estimate average terms on C\&I loans of various types extended during the survey period. Since May 1997, the survey has collected information on banks' internal risk ratings on loan extensions. Specifically, banks are asked to allocate C\&I loans they made during the survey week among five risk categories, ranging from "minimal risk" to "special mention." As detailed in Appendix 1, explicit instructions are provided regarding the allocation of loans to these categories.

We have mapped the reported STBL risk categories into the Basel risk-weight categories as follows: "minimal risk" loans received a 20 percent risk weight, "low risk" a 50 percent weight, "moderate" a 100 percent weight, and "acceptable risk" and "special mention" loans-the latter generally being workout loans-were assigned a 150 percent risk weight. Lastly, in keeping with the proposed standardized approach, business loans for which no rating was reported (about 6 percent of the estimated C\&I loans outstanding) were assigned a 100 percent weight. ${ }^{-1}$

\footnotetext{
${ }^{3}$ The survey period is the first full business week of the middle month of each quarter. Up to 350 insured domestic commercial banks and up to 50 foreign-related institutions from all parts of the country are included in the survey, resulting in around 40,000 bank/loan observations in a typical survey. The respondents are divided into seven strata—six for the domestic banks and one for the branches and agencies of foreign banks - based on the business loan volume to U.S. addressees; see Brady, English, and Nelson (1998) and English and Nelson (1998) for a detailed description of the survey. ${ }^{4}$ Following English and Nelson (1998), we omitted from our analysis any bank that did not assign internal risk ratings to C\&I loans. In other words, a loan was classified as unrated only if the bank, in general, rated loans but did not rate that particular loan. If a bank reported all of its loans as unrated, we dropped it from the sample. More than threequarters of banks surveyed had an internal risk rating system, which they were able to
} 
To verify that banks' ratings of business loans in the STBL reflect differences in risk, we estimated the implied risk premium for each risk-weight category. As discussed by English and Nelson (1998), there are many other loan characteristics—in addition to a risk rating - that may affect the observed interest rate on any particular loan. Following their methodology, we regressed the effective interest rate for each loan on a set of loanspecific control variables (e.g., loan terms, loan size, days to maturity, repricing frequency, etc.) and its risk-weight category under the standardized approach of the new Accord.

Exhibit 2 plots the estimated risk premiums measured relative to minimal-risk loans from the second quarter of 1997 through the end of 2000. Consistent with the reported ratings, the implied risk premiums increase as one moves from low-risk loans (50 percent risk weight) to acceptable-risk or classified loans (150 percent risk weight). Further, unrated and moderate-risk loans, both of which are assigned a 100 percent risk weight under the standardized approach, have comparable risk premiums.

A potential limitation of the raw STBL data is that they are based on loan extensions during the survey week. As indicated in Appendix 2, we made several adjustments to translate loan originations into estimates of outstanding loans in each risk category. Exhibit 3 presents the estimated C\&I loan portfolio shares across the risk categories of the standardized approach. The shares are shown for all banks in the STBL, and separately for large and small domestic banks, as well as U.S. branches and agencies of foreign banks.

match to the STBL risk categories. These banks accounted for about 87 percent of the estimated C\&I loans outstanding.

5 The complete set of control variables and details of the estimation can be found in Appendix 1. 
For all but the foreign institutions, the 100 percent risk category accounted for the largest share of outstanding C\&I loans throughout the sample ${ }^{6}$ In addition, the share of business loans in this category at domestic banks has been remarkably stable, at just under 50 percent. Driven mainly by the distributional changes of C\&I loan portfolios at large domestic banks, the portion of loans in the 20 percent risk-weight category has risen gradually since the second quarter of 1997 for the banking sector as a whole, while the relative importance of loans in the 50 percent and 150 percent risk-weight categories has declined.

\section{Capital Level Effect of the New Accord}

One effect of the new Accord can be computed from the time-varying risk distributions shown in Exhibit 3. At each point in time and for each bank type, we multiplied the portfolio shares by their corresponding risk weights and summed the results. This provided time-series estimates of the ratio of risk-weighted C\&I loans under the standardized approach in the new Accord relative to the risk-weighted loans in the existing regime, shown in Exhibit 4. (Recall that, under the existing regime, all C\&I loans are assigned a 100 percent risk weight, and risk-weighted loans are therefore just the level of outstanding loans.) Because the minimum capital requirements (tier 1 and total) against risk-weighted assets are expected to be the same in the new Accord as under the existing regime, our time-series of the ratios of risk-weighted C\&I loans are

${ }^{6}$ The considerable variability of the risk shares at U.S. branches and agencies of foreign banks, relative to large domestic banks, is in part due to the fact that these institutions tend to make, on average, fewer but larger loans than their respective U.S. counterparts. The evolving attitudes toward credit risk held by their parent institutions over this period may also have contributed to the volatility of portfolio shares. 
also the ratios of the expected minimum capital required against these loans under the new Accord relative to the existing regime.

According to these estimates, the industry-wide level of required capital against C\&I loans under the new Accord would have been about equal, on average, to the level mandated by the current regulatory framework until the end of 1998 (top left panel of Exhibit 4). Despite the deterioration in overall credit quality associated with the financial turmoil following the Russian default in the fourth quarter of 1998, the level of required capital against C\&I loans under the new Accord would have fallen to about 90 percent of that required in the existing regime, on average, over the remainder of the sample period. This drop in relative required capital since 1998, primarily at large domestic banks, was likely due in part to the tightening of standards by banks on business lending in response to the deteriorating quality of C\&I loan portfolios, which is a typical cyclical pattern of bank behavior that is independent of capital requirements.

Next, we calculated the average risk distribution of C\&I loans outstanding for each type of bank in the STBL over the 1997-2000 period, as shown in Exhibit 5. The Treacy-Carey large-bank risk profile is shown for comparison in the lower left panel of that exhibit. We also show, in the inset boxes, the average ratio of risk-weighted loans and therefore of required capital against these loans. The industry-wide ratio of 0.935 implies that, on average over recent years, banks would have been required to hold 6.5 percent less capital against C\&I loans under the new Accord than they were under the prevailing regime. ${ }^{\square}$ The greatest reduction in required capital, more than 9 percent,

\footnotetext{
${ }^{7}$ If unrated loans were included in the 150 percent risk-weight category instead of the 100 percent category, the average ratio of regulatory capital under the new Accord,
} 
would have been at large domestic banks in the STBL. By contrast, branches and agencies of foreign banks would have been little affected.

The estimated reduction in required capital under the standardized approach of the new Accord would actually apply only to C\&I loans extended to borrowers rated by external agencies, and such loans are likely to account for a small portion of C\&I loan portfolios for many banks. On the other hand, banks that use an internal-ratings-based approach may well have reductions in required capital on C\&I loans of the magnitude indicated here. Moreover, an additional caveat to our finding is the possibility that upon implementation of the new Accord, banks may undertake shifts among other assets in their portfolio. Furfine (2001), for instance, develops a dynamic banking model in which a representative bank implementing the standardized approach responds by reallocating some of their securities investments in favor of loans. Although the average risk weight of loans decreases in his model—as it does in our calculations - the riskiness of the overall portfolio rises, owing to a relatively higher portfolio share accounted for by loans.

For large domestic banks, the STBL and the Treacy-Carey risk profiles give slightly different answers. According to Treacy and Carey, almost 70 percent of C\&I loans at the end of 1997 fell into the 100 percent risk-weight category. In the STBL portfolio, this category represented a smaller share, while lower risk categories accounted for noticeably larger portions, both on average and at the end of 1997. As a consequence,

relative to the existing regime, would be 0.963 , implying a reduction in required capital of only 3.7 percent. 
the weighted-average capital requirement was slightly higher for the Treacy-Carey

portfolio than for the large domestic bank portfolio in the STBL.

A lower capital requirement may itself imply a dampening of any cyclical effects of capital regulation. A vast majority of banks apparently target a level of capital that exceeds minimum requirements by some cushion. This behavior is evident in Exhibit 6, which shows the "well-capitalized" margin—a measure of how close banks are, on average, to the minimum acceptable criteria for being classified as well capitalized. ${ }^{0}$ The average margin by which domestic commercial banks were well capitalized edged down over the last decade from around 3 to 1-3/4 percentage points, perhaps suggesting greater confidence on the part of banks and capital markets in the ability of banks to manage risks. The share of the industry's assets accounted for by well-capitalized institutions has been above 95 percent since the mid-1990s.

The exact motivation for holding capital in excess of the regulatory minimum is not clear. Some institutions may hold excess capital but nevertheless be responsive to regulatory requirements, because they target a specific cushion of capital above the

\footnotetext{
${ }^{8}$ The Treacy-Carey sample, based on outstanding loan portfolios, may be on average lower-rated than the STBL data in part because it reflects seasoning effects. Upon origination, a group of loans may be appropriately placed in, for example, a 50 percent risk-weight category. Although a few firms may be upgraded from their initial rating, more loans, on average, would tend deteriorate over time-perhaps on their way to default — and need to be reclassified into the 100 percent or 150 percent risk-weight categories.

${ }^{9}$ The well-capitalized margin for domestic commercial banks, a concept developed for internal work at the Federal Reserve Board by William Nelson, is constructed as follows: In any given quarter, we used Call Report data to compute for each bank with a CAMEL rating of 1 or 2 the spread between a bank's leverage, tier 1, and total capital ratios and the corresponding regulatory thresholds for being well capitalized in each category: 5 percent for the leverage ratio, 6 percent for the tier 1 capital, and 10 percent for the total capital ratio. We then took the minimum spread for each bank and computed the average over all banks of these minimums, weighted by each bank's total assets.
} 
required level; see, for instance, Hancock and Wilcox (1994). Other banks may target a higher capital level solely because of internal management preferences and market realities, and for them capital regulation may have no effect on behavior, even at a time

of economic downturn. A lower average level of required capital under the new Accord, relative to the current regime, would tend to increase the number of banks in such a position, implying — from this effect—a reduction in any procyclicality attributable to capital regulation.

\section{Variability in Required Capital}

The available STBL data on internal risk ratings do not cover a full business cycle. However, they do provide some indication of the relative variability of capital requirements. For every quarter from 1997 through 2000, we computed the level of the total capital requirement against $\mathrm{C} \& \mathrm{I}$ loans under each regulatory regime, that is, 8 percent of risk-weighted loans. (Under the existing regime, the level of risk-weighted loans is equal to outstanding loans.) We then calculated the coefficient of variation of the total capital requirement under each regime over this period.

Although caveats are in order because of the small sample size, the resultsshown in Table 2-suggest that capital requirements would have been slightly less volatile under the new Accord for the industry as a whole (a 12 percent coefficient of variation versus 15 percent under the existing regime). Evidently, when loans were growing rapidly, there was a tendency for the distribution of loans to shift to less risky borrowers. For branches and agencies of foreign institutions, however, the capital 
requirement would have been more volatile under the new Accord than in the existing regime.

The third row of the table shows the ratio of the variance of quarterly capital requirements under the new Accord to that of the existing regime. The industry-wide ratio indicates that the variance of capital requirements under the new Accord would have been only about 55 percent of the variance under the existing regime. Assuming normality, this variance ratio has an $F$-distribution, and the p-values in row 4 indicate that the differences in the variances were not statistically significant.

\section{Counterfactual Required Capital Series}

In order to look more directly at potential cyclical effects, we constructed a counterfactual historical series of the estimated required capital on C\&I loans under the new Accord compared with the existing regime. We combined data either from the STBL or from the Treacy-Carey sample on loan portfolio shares by risk category with historical transition matrices for bond ratings by Moody's. We used the two risk profiles as proxies for the initial portfolio of a representative bank, and we allowed this portfolio to evolve thereafter according to Moody's transition probabilities.

More formally, let $f_{t}$ denote the representative bank's portfolio distribution of loans by risk category in period $t$, and let $\Gamma_{t, t+j}$ denote the probability transition matrix from period $t$ to period $t+j$. We take the resulting distribution of loans in period $t+j$ to be $f_{t+j}=\Gamma_{t, t+j} f_{t}$. This estimate implicitly assumes that any new loans originated over the period are drawn from the risk distribution in period $t+j$, which would be appropriate for new drawdowns on previously committed lines of credit. This assumption may tend to 
overestimate slightly the degree of change in the portfolio, however, as banks may in the case of new loan commitments grant credit to a safer profile of borrowers when existing loans are being downgraded. In using Moody's transition matrices, we are also implicitly assuming, as noted above, that the probability of a change in risk class, for loans within the same class, is independent of the size of the loan.

In constructing the counterfactual series, we removed the effects of defaults. In each quarter, we eliminated any firms that defaulted over the quarter and then recomputed the percentages of transitioning firms. This adjustment was necessary because, once a firm falls into default, it is dropped from Moody's analysis of rating transitions. Continuing to carry such firms in our simulated portfolio would increasingly exaggerate their importance over time, especially because of the assumption we needed to make that new issuance matches the risk distribution of the contemporaneous portfolio. In addition, the probability of a firm going into default, and the hit to bank capital from such defaults, is unlikely to differ across the two capital regulatory regimes that are being compared.

Our time series of the relative required capital under the standardized approach of the new Accord starts at the beginning of the first quarter of 1970, at which time we assumed that banks hold the average risk distribution of loans computed from the STBL data or the Treacy-Carey risk distribution. We computed subsequent risk distributions by applying the sequence of quarter-to-quarter transition matrices. We then multiplied portfolio shares by risk weights to obtain an estimated ratio of required capital under the new Accord relative to the existing regime. 
Exhibit 7 plots the time path of this counterfactual ratio for the banking sector as a whole, using the STBL portfolio data, with the shaded regions again indicating NBERdated recessions. No clear cyclical pattern emerges in this estimate of the ratio of required capital under the new Accord relative to the current regime. Moreover, the variation in required capital against $C \& I$ loans almost surely overstates what would have been the actual effect, because the majority of C\&I loans on banks' books are likely made to firms that are not rated by external agencies. These loans would continue to carry a risk weight of 100 percent under the standardized approach of the new Accord, the same as under the existing capital regime.

Aside from the lack of cyclical fluctuations in required capital against C\&I loans, four distinct secular trends are clearly evident in Exhibit 7: 1970 through 1984, 1985 through 1991, 1992 through 1998, and the last two years. To help elucidate the reasons for the different trends in these subperiods, we computed the average of the quarterly transition matrices for each subperiod (Tables 3-6).

The decline in the required capital ratio over the 1970-84 period reflects a relatively large number of upgrades for lower-rated firms over that period (Table 3), which would have increased the gap between the current regime and the new Accord. The rise in the ratio over the late 1980s (Table 4) is indicative of the general deterioration of credit quality during that period, which featured many mergers through leveraged buyouts. It may also reflect a willingness on the part of firms to accept a downgrade into speculative-grade status, following the development of the junk bond market. Formerly, firms may have tended to withdraw from the pool of rated borrowers, rather than accept a loss of investment-grade status. Finally, the rise in the required capital ratio over this 
period may be due in part to a tightening of rating standards by Moody's, along with other rating agencies, as suggested by Blume et al. (1998).

The stability of the ratio over most of the 1990s (Table 5) is likely attributable to the generally favorable economic performance during that time. The sharp rise in the ratio in 1999—-subsequent to the financial turmoil in late 1998 sparked by the Russian default—would imply an increase in risk-weighted C\&I loans and associated required capital of more than 3 percent. At that time, Moody's downgraded a number of firms that conducted substantial amounts of business in countries affected by sovereign downgrades, most notably Russia and Brazil. This phenomenon was also noted above in the discussion of risk-weight shares shown on the lower panel of Exhibit 1.

In the top panel of Exhibit 8, we repeated the counterfactual simulation using the Treacy-Carey risk profile, rather than the STBL data, for the initial risk distribution of C\&I loans. Except for a small upward level shift-reflecting the fact that the TreacyCarey loan portfolio was rated as, on average, more risky than the portfolio of large domestic banks in the STBL_- the time path of simulated required capital is virtually identical to the time path generated with the STBL data. This might have been expected, as the same transition matrices were used in either case.

As another possible estimate of the capital that would have been required over history under the standardized approach of the new Accord, we assumed that the risk distribution of the C\&I loan portfolio of a representative bank matched the risk distribution of firms with ratings from Moody's on senior unsecured debt at the beginning of each quarter. Thus, we used the shares of firms across risk categories shown in the lower panel of Exhibit 1 to compute the ratio of required capital under the 
new Accord relative to the current regulatory framework. The resulting time series, shown in the bottom panel of Exhibit 8, again shows a trend increase in required capital in the period since the mid-1980s, reflecting the development of the junk bond market. Also, as in the previous simulations, no obvious cyclical pattern emerges in this estimate of the ratio of required capital under the new Accord relative to the current regime.

Fluctuations in required capital, however, were more pronounced in the first half of the 1990s. Moody's distribution data suggest a sharp reduction in required capital in the two-year period including the 1990-91 recession, which may have reflected the near shut down of the junk bond market and the exiting of lower-rated firms from Moody's universe of rated borrowers. The rise in the required capital ratio over the mid-1990s may have been due to the gradual return of borrowers to the junk bond market. By contrast, the transition matrix data, which underlie the charts using the STBL and TreacyCarey initial portfolios, show a more stable pattern of required capital from 1991 through 1998. Downgrades and upgrades were evidently not as pronounced as the entry and exit of firms into and out of the rated universe.

\section{Recession-Specific Effects}

To focus on business downturns in more detail, we next examined the implied change in risk-weighted loans over each recession in the sample. We constructed transition matrices between the quarter of the NBER-dated business cycle peaks and the quarter of the trough. 10 In these cases, we assigned firms that defaulted over the

${ }^{10}$ We also experimented with including a quarter before and after the NBER dates; this variation made almost no difference. 
recession to the 150 percent risk-weight category. 11 The transition matrices for the four recessions are shown in Tables 7 through 10.

We used the average risk distribution estimated from the STBL as a benchmark starting point for bank C\&I loan portfolios prior to each recession. After applying the relevant recession-specific transition matrix, we computed the percentage change in riskweighted assets over each recession. As shown in Table 11, these changes were rather small.

The percentage changes in risk-weighted C\&I loans would have been equivalent to the percentage changes in required capital against such loans. Surprisingly, net upgrades over the 1970 recession would have led to a reduction in required capital. Although other recessions were associated with more substantial and protracted declines in real output, the largest rise in required capital, under this measure of the standardized approach, occurred during the 1990-91 recession. The increase in required capital during this period was caused by the sizable net downgrades, reflecting the effect on rated firms of the collapse of leveraged buyouts and the junk bond market, which was not entirely a cyclical phenomenon. Even in this case, however, the increase in risk-weighted assets was less than one percent, smaller than the average margin by which banks remain wellcapitalized, as shown in Exhibit 6.

Another method of assessing recession-specific effects involved detrending the counterfactual time series ratio, shown in Exhibit 7, of required capital under the new Accord relative to the existing regime. Using this series for all banks, we fitted a time trend through the 1970-2000 period, using the "loess" method, as in Cleveland, Devlin,

${ }^{11}$ Excluding firms that defaulted over the recession period had virtually no effect on our results. 
and Grosse (1988). The trend was estimated as a smooth function of time at each point, using a quadratic polynomial fit through nearby data points. 12 In Exhibit 8, the top panel shows the estimated trend, along with the original series.

In the lower panel of Exhibit 9, we plotted the deviation from trend of the ratio of capital for each of the recessions in our sample. The zero quarter represents the quarter in which the recession began. As shown, these estimates of the detrended ratio of required capital in the new Accord, relative to the existing regime, increase noticeably only for the 1973-75 recession. The magnitude of the incremental increase in required capital in that case was nevertheless still rather small at around one percent. (The Vshaped pattern late in the early 1980s recession period again reflects the effects of the reconstitution of ratings undertaken by Moody's at that time, as noted above.)

It may be interesting to compare the above results with the findings of Nickell, Perraudin, and Varotto (2000), hereafter NPV. Investigating annual transition matrices of Moody's issuer ratings, NPV examined differences in the probability of a downgrade, depending on whether the economy was in a high-growth versus low-growth period. ${ }^{13}$ After controlling for industry and location, they found that most of the differences in the

12 In the loess method, data points in a given local neighborhood are weighted by a smooth decreasing function of their distance from the center of the neighborhood. The radius of each neighborhood-which controls the smoothness of the estimated time trend-was chosen to contain 20 percent of the overall data points. The estimated trend was quite insensitive to variation in the size of the neighborhood between 15 and 30 percent. The Hurvich and Simonoff (1998) Akaike Information Criterion (AIC) for loess regressions indicated essentially no improvement in fit when the neighborhood was decreased from 20 to 15 percent, while increasing the size of the neighborhood from 20 to 25 percent registered a notable deterioration in the AIC. Because the distribution of the errors is likely to be fat-tailed and contaminated by outliers, we used iterative reweighting (50 iterations) at each point to improve the robustness of the fit; see Cleveland and Grosse (1991) for details.

${ }^{13}$ High- and low-growth periods were defined as the upper third and lower third of the distribution of annual growth rates for G-7 countries. 
probability of a downgrade, depending on growth phase, were not statistically significant, although a few were and the differences generally had the right sign. NPV concluded that "the effect of the cycle on [investment-grade] obligors is more to raise volatility than to shift ratings systematically down." In addition, NPV used a more refined grading than would apply under the new Accord and, as a consequence, some of their downgrades would not result in any change in capital requirements in the new regime. Nevertheless, their results are consistent with our finding that Moody's transition matrices suggest the possibility of some increased procyclicality in capital requirements under the new Accord. However, the NPV results do not contradict our conclusion that the overall magnitude of any such increased procyclicality is likely to be very small.

\section{Concluding Comments}

This paper provided an initial attempt to examine empirically the potential cyclical effects of the proposed new Basel Accord relative to the existing capital regulatory framework. We combined data from Moody's Investors Services on corporate borrowers' ratings with information from the Survey of Terms of Business Lending to derive time series estimates of required capital as if the new Accord had been in place since 1970. Our methods allow us to comment only on the "standardized approach" of the new Accord, which allows banks to employ external ratings to evaluate the riskiness of their C\&I loans.

The results suggest very little cyclical impact of the standardized approach of the new Accord relative to the existing capital regime. Indeed, our result may overstate the cyclical movement of required capital on C\&I loans under this approach, because only a 
small portion of business borrowers are likely to have ratings by external agencies. Further, the ratings of external agencies, such as Moody's, take into account possible economic downturns, and these ratings do not seem to deteriorate markedly over the course of a recession. The changes in ratings that have occurred over those intervals do not appear to have been substantial enough to have caused much increase in the riskweighted portfolio of C\&I loans on banks' books. On the other hand, the rating agencies may undertake comprehensive reviews of the position of firms from time to time, as Moody's reportedly did after the financial turmoil in late 1998. The net downgrades at such times may imply sizable revisions to risk-weighted assets and required capital, suggesting possible industry-wide effects of the standardized approach of the new Accord that may not be explicitly cyclical in nature.

Another effect of the standardized approach of the new Accord, evident from this analysis, would be a reduction in the average level of capital that would be required against C\&I loans, relative to the existing regime. The lower level of capital requirements might make the regulation less binding for some institutions, which could itself imply a slight attenuation of cyclical effects.

There are a number of caveats regarding our results, however, which point to the possibility for additional empirical research in this area. Data on the structure of bank C\&I loan portfolios by risk category are not available over most of history. We used initial risk distributions of loan portfolios based on internal bank ratings in recent years for which data are available, but these distributions may not correspond well to historical risk profiles. In addition, the fraction of borrowers with external ratings likely represents a small portion of banks' C\&I loan portfolios, and the capital required against unrated 
loans will be the same under the standardized approach of the new Accord. Finally, the available bond rating data are based on the number of issuers, not the value of bonds outstanding in each risk category and may not in any case exactly match the migration dynamics of bank borrowers.

More fundamentally, the behavior of banks using the standardized approach in the new Accord, which is based on through-the-cycle ratings of external agencies, may differ from that of banks using internal-risk-based (IRB) approaches, which involve risk assessments over a one-year-ahead horizon. Because of the shorter horizons in IRB approaches, they would likely imply greater variation in required capital through time than the standardized approach. However, it is not clear how large the resulting fluctuations in required capital would be or how they would coincide with the business cycle. If banks adjust internal ratings on individual loans only slightly more frequently than Moody's, the cyclical effects would evidently be quite limited.

On the other hand, if banks make few adjustments in internal ratings as an economic expansion matures and then downgrade sizable portions of their portfolios at the onset of a recession, noticeable procyclical effects on required capital could occur. In that case, banks might respond to the higher capital requirements by restricting lending or by adjusting loan supplies to favor less risky firms. However, these behaviors already tend to occur in business downturns, and the extent to which they might be incrementally increased is unclear. While questions remain regarding IRB approaches, this paper has shown that at least the standardized approach of the new Accord is unlikely to induce material increases in procyclicality. 


\section{$\underline{\text { References }}$}

Altman, E. and A. Saunders, (2001), An analysis and critique of the BIS proposal on capital adequacy and ratings. Journal of Banking and Finance, (25), 25-46.

Bernanke, B., M. Gertler, and S. Gilchrist, (1999), The financial accelerator in a quantitative business cycle framework. In the Handbook of Macroeconomics, edited by J. Taylor and M. Woodford, North Holland, 1341-1393.

Bernanke, B. and C. Lown (1991), The credit crunch. The Brookings Papers on Economic Activity, (2), 205-239.

BIS Committee on Banking Supervision (2001), The new Basel capital accord. Bank for International Settlements, January.

Blum, J. and M. Hellwig (1995), The macroeconomic implications of capital adequacy requirements for banks. European Economic Review, (39), 739-749.

Blume, M., F. Lim, and C. MacKinlay, (1998), The declining credit quality of U.S. corporate debt: myth or reality? Journal of Finance, (53), 1389-1413.

Borio, C., C. Furfine, and P. Lowe (2001), Procyclicality of the financial system and financial stability: issues and policy options. Mimeo, Bank for International Settlements.

Brady, T., W. English, and W. Nelson (1998), Recent changes to the Federal Reserve's Survey of Terms of Business Lending. Federal Reserve Bulletin, August, 604615.

Cantor, R. (2001), Moody's investors service response to the consultative paper issued by the Basel Committee on Bank Supervision "A new capital adequacy framework." Journal of Banking and Finance, (25), 171-185. 
Carey, M. and M. Hrycay (2001), Parameterizing credit risk models with rating data. Journal of Banking and Finance, (25), 197-270.

Carty, L. (1997), Moody's rating migration and credit quality correlation. Mimeo, Moody's Investor Service, July.

Cleveland, W., S. Devlin, and E. Grosse (1988), Regression by local fitting. Journal of Econometrics, (37), 87-114.

Cleveland, W. and E. Grosse (1991), Computational methods for local regression. Statistics and Computing, (1), 47-62.

English, W. and W. Nelson (1998), Bank risk rating of business loans. Finance and Economics Discussion Series Paper No. 51, Federal Reserve Board.

Furfine, Craig (2001), Bank portfolio allocation: The impact of capital requirements, regulatory monitoring, and economic conditions. Journal of Financial Services Research, (20), 33-56.

Gertler, M. and S. Gilchrist (1993), The role of credit market imperfections in the monetary transmission mechanism: arguments and evidence. Scandinavian Journal of Economics, (95), 43-64.

Hancock, D. and J. Wilcox (1994), Bank capital, loan delinquencies, and real estate lending. Journal of Housing Economics, (3), 121-146.

Haubrich, J. and P. Wachtel (1993), Capital requirements and shifts in commercial bank portfolios. Economic Review, Federal Reserve Bank of Cleveland, (29-3), 2-15.

Heid, F. (2000), Capital requirements and macroeconomic fluctuations. Mimeo, Deutsche Bundesbank. 
Hurvich, C. and J. Simonoff (1998), Smoothing parameter selection in nonparametric regression using an improved Akaike information criterion. Journal of the Royal Statistical Society B, (60), 271-293.

Kashyap, A. and J. Stein (1997), The role of banks in monetary policy: A survey with implications for the European Monetary Union. Economic Perspective, Federal Reserve Bank of Chicago, September-October, 2-18.

Nickell, P., W. Perraudin, and S. Varotto (2000), Stability of rating transitions. Journal of Banking and Finance, (24), 203-227.

Treacy, W. and M. Carey (1998), Credit risk rating at large U.S. banks. Federal Reserve Bulletin, November, 897-921. 


\section{Appendix 1: Risk Categories in the Survey of Terms of Business Lending (STBL)}

Banks in the survey are instructed to map their internal risk ratings of business loans (provided they have an internal ratings system) to risk categories that most closely matches the definition of the internal rating assigned to this loan. If an institution rates loans, but a particular loan is unrated, or not yet rated, banks must enter "0" for that loan. If a bank does not assign internal risk ratings to business loans, the respondent can either leave the answer blank or use the categories listed below to make an assignment. The risk rating categories are defined as follows:

\section{Minimal Risk Loans}

Loans in this category have virtually no chance of resulting in a loss. They would have a level of risk similar to a loan with the following characteristics:

- The customer has been with your institution for many years and has an excellent credit history.

- The customer's cash flow is steady and well in excess of required debt repayments plus other fixed charges.

- The customer has an AA or higher public debt rating.

- The customer has excellent access to alternative sources of finance at favorable terms.

- The management is of uniformly high quality and has unquestioned character.

- The collateral, if required, is cash or cash equivalent and is equal to or exceeds the value of the loan.

- The guarantor, if required, would achieve approximately this rating if borrowing from your institution.

We assigned a 20 percent risk weight to minimal risk loans.

\section{Low Risk Loans}

Loans in this category are very unlikely to result in a loss. They would have a level of risk similar to a loan with the following characteristics:

- The customer has an excellent credit history. 
- The customer's cash flow is steady and comfortably exceeds required debt repayments plus other fixed charges.

- The customer has a BBB or higher public debt rating.

- The customer has good access to alternative sources of finance at favorable terms.

- The management is of high quality and has unquestioned character.

- The collateral, if required, is sufficiently liquid and has a large enough margin to make very likely the recovery of the full amount of the loan in the event of default.

- The guarantor, if required, would achieve approximately this rating if borrowing from your institution.

Loan in this category were assigned a 50 percent risk weight.

\section{$\underline{\text { Moderate Risk Loans }}$}

Loans in this category have little chance of resulting in a loss. This category should include the average loan, under average economic conditions, at the typical lender. Loans in this category would have a level of risk similar to a loan with the following characteristics:

- The customer has a good credit history.

- The customer's cash flow may be subject to cyclical conditions, but is adequate to meet required debt repayments plus other fixed charges even after a limited period of losses or in the event of a somewhat lower trend in earnings.

- The customer has limited access to the capital markets.

- The customer has some access to alternative sources of finance at reasonable terms.

- The firm has good management in important positions.

- Collateral, which would usually be required, is sufficiently liquid and has a large enough margin to make likely the recovery of the value of the loan in the event of default.

- The guarantor, if required, would achieve approximately this rating if borrowing from your institution.

Moderate risk loans were assigned a 100 percent risk weight. 


\section{Acceptable Risk Loans}

Loans in this category have a limited chance of resulting in a loss. They would have a level of risk similar to a loan with the following characteristics:

- The customer has only a fair credit rating but no recent credit problems.

- The customer's cash flow is currently adequate to meet required debt repayments, but it may not be sufficient in the event of significant adverse developments.

- The customer does not have access to the capital markets.

- The customer has some limited access to alternative sources of finance possibly at unfavorable terms.

- Some management weakness exists.

- Collateral, which would generally be required, is sufficient to make likely the recovery of the value of the loan in the event of default, but liquidating the collateral may be difficult or expensive.

- The guarantor, if required, would achieve this rating or lower if borrowing from your institution.

Loans in the acceptable risk category were assigned a 150 percent risk weight.

\section{Special Mention or Classified Asset}

Loans in this category would generally fall into the examination categories: "special mention," "sub-standard," "doubtful," or "loss." They would primarily be work-out loans, as it is highly unlikely that new loans would fall into this category.

Loans rated as special mention or classified asset were assigned a 150 percent risk weight.

\section{Estimating Risk Premiums}

The dependent variable in the regression is the effective loan rate. The regressors are indicator variables corresponding to the risk-weight categories in the standardized approach and control variables. The control variables are: 
- An indicator variable for whether a loan was made under a previous commitment.

- An indicator variable for whether a loan was secured by collateral.

- An indicator variable for whether a loan was callable.

- An indicator variable for whether a loan had a prepayment penalty.

- A set of indicator variables for the loan base pricing rate: prime rate, federal funds rate, other domestic rate, and foreign (LIBOR or eurodollar) rate.

- The logarithm of loan size.

- Loan maturity controls:

1. An indicator variable for whether a loan had no stated maturity.

2. An indicator variable for whether it was an overnight loan.

3. For loans with stated maturity greater than one day, the logarithm of days to maturity.

- Loan repricing controls:

1. An indicator variable for whether a loan was a fixed rate loan.

2. An indicator variable for whether a loan could have been repriced at anytime.

3. An indicator variable for whether a loan had a repricing interval of one day.

4. For loans with a repricing interval greater than one day, the logarithm of days to the next repricing.

- Bank-specific fixed effects to control for factors such as possible differences in interpretation of the common set of ratings used in the survey and bank-specific attitudes toward risk.

The equation was estimated for each survey period separately. The implied risk premiums in Exhibit 2 are the weighted least squares estimates of the coefficients on the risk categories measured relative to minimal risk loans. The weights used in estimation are proportional to the "blow-up" factors corresponding to the seven strata in the survey. Because larger banks are allowed to report for only a fraction of the survey week or for only a subset of their offices, the blow-up factors are adjusted so that the actual weights reflect the panel's coverage of C\&I loans by banks in each 
stratum. The same weights are used to calculate estimates of average terms on business loans of various types at all commercial banks during the survey week, which are published in the Federal Reserve's E.2 statistical release. 


\section{Appendix 2: Calculation of Portfolio Shares from STBL Data}

We used the Survey of Terms of Business Lending (STBL) to estimate the risk distribution of the stock of outstanding C\&I loans. Because the STBL measures gross loan extensions issued over a statement week, the data tend to overweight loans with short maturities as a representation of the outstanding portfolio. For instance, five successive overnight loans should have the same effect on portfolio shares as a one-week loan of equal size, but the extension data would give the overnight loans five times the weight of the one-week loan.

To adjust for these effects, we followed the methodology developed by Thomas Brady, Douglas Conover, and William Nelson in an internal memorandum, "Choice of Weights When Calculating Average STBL Loan Rates," June 30, 1999 (BCN hereafter). $\mathrm{BCN}$ assumed that the distribution of outstanding loans does not change over the statement week, so that all extensions can be interpreted as rollover loans. They then adjusted loans for their maturities to estimate their importance in bank portfolios. For instance, overnight loan extensions are divided by five, while extensions of two-week loans are multiplied by two in computing portfolio shares. In general, the industry-wide C\&I loan portfolio consistent with a measured weekly loan flow is the sum of loan originations times their maturities in days divided by five for loans with maturities less than one week, plus the sum of loan originations having maturities of a week or more multiplied by their maturity in weeks.

Because banks report loan maturity on the STBL, this methodology could, in principle, be implemented to estimate the stock of loans outstanding in any given quarter. However, as noted by BCN, there are two problems with this approach: 
1. On average, loan maturities reported by banks typically exceed realized maturities.

2. How to measure the ex post maturity (EPM) of loans that are reported as having no stated maturity, which account for a nontrivial fraction of loan originations.

To deal with the first problem, BCN assumed that each loan in the STBL faced a constant probability $(p)$ every day of being called or repaid. This assumption implies that a loan's realized maturity $(R M)$ has a probability distribution that is exponential relative to its stated maturity $(S M)$ :

$R M=\frac{1-\exp (-p \times S M)}{p}$

Under this assumption, loans with shorter stated maturities have realized maturities that are about equal to their stated maturities. For longer-term loans, the realized maturity tends to $1 / p$ as $S M \rightarrow \infty$.

To find values for $p$ and EPM, BCN conducted a grid search over values of these two parameters by running a series of regressions of respondent banks' outstanding C\&I loans, taken from the Call Report, on the sum of loans with a stated maturity multiplied by their respective realized maturity $R M$, and the sum of loan with no stated maturity, multiplied by EPM. These regressions were run separately for large domestic, small domestic, and foreign banks for selected years from 1986 to 1999. The value of parameters $p$ and EPM that minimized the regressions' standard error were a repayment frequency $(p)$ of 0.005 for large domestic banks and foreign institutions and an EPM of 200 days for loans made by these institutions. For small banks, the method yielded a repayment frequency of 0.002 and an EPM of 180 days. 


\begin{tabular}{|c|c|c|c|c|c|}
\hline \multicolumn{6}{|c|}{ Table 1: Average of Quarterly Rating Transition Matrices (1970-2000) } \\
\hline \multicolumn{6}{|c|}{$\begin{array}{c}\text { From } \\
\text { Risk-Weight Category }\end{array}$} \\
\hline \multirow{6}{*}{ To } & & $20 \%$ & $\underline{50 \%}$ & $100 \%$ & $150 \%$ \\
\hline & $20 \%$ & $\overline{0.984}$ & $\overline{0.006}$ & $\overline{0.000}$ & $\overline{0.000}$ \\
\hline & $50 \%$ & 0.015 & 0.980 & 0.007 & 0.000 \\
\hline & $100 \%$ & 0.000 & 0.014 & 0.981 & 0.017 \\
\hline & $150 \%$ & 0.000 & 0.000 & 0.010 & 0.958 \\
\hline & Default & 0.000 & 0.000 & 0.001 & 0.025 \\
\hline
\end{tabular}

\begin{tabular}{|c|c|c|c|c|}
\hline \multicolumn{5}{|c|}{ Table 2: Variability of Risk-Weighted C\&I Loans } \\
\hline \multirow{4}{*}{$\begin{array}{c}\mathrm{CV} \\
\text { (current Accord) } \\
\text { CV } \\
\text { (proposed Accord) }\end{array}$} & All & Large Domestic & Small Domestic & Foreign \\
\hline & Banks & Banks & Banks & Banks \\
\hline & 0.152 & 0.255 & 0.159 & 0.191 \\
\hline & 0.121 & 0.207 & 0.156 & 0.274 \\
\hline$F$-statistic & 0.556 & 0.540 & 0.909 & 2.033 \\
\hline $\mathrm{p}$-value & 0.284 & 0.261 & 0.860 & 0.197 \\
\hline $\begin{array}{l}\text { Notes: Sample perio } \\
\text { risk-weighted C\&I } 1 \\
\text { C\&I loans under the } \\
\text { of risk-weighted C\& } \\
\text { significance level at } \\
\text { rejected. }\end{array}$ & $\begin{array}{l}997: \mathrm{Q} 2- \\
\text { s. } F \text {-stat } \\
\text { posed st } \\
\text { ans unde } \\
\text { ch the n }\end{array}$ & $\begin{array}{l}0: Q 4 . \mathrm{CV} \text { denote } \\
\text { denotes the ratio } \\
\text { ardized approach } \\
\text { e current regulato } \\
\text { typothesis that the }\end{array}$ & $\begin{array}{l}\text { the coefficient of } \\
\text { of the variance of } \\
\text { f the new Accord } \\
y \text { framework; } p-v \\
\text { ratio is equal to } u\end{array}$ & $\begin{array}{l}\text { tion of th } \\
\text { weighted } \\
\text { e variance } \\
\text { s the } \\
\text { an be }\end{array}$ \\
\hline
\end{tabular}

\begin{tabular}{|c|c|c|c|c|c|}
\hline \multicolumn{6}{|c|}{ Table 3: Average Rating Transition Matrix for 70:Q1-84:Q4 } \\
\hline \multicolumn{6}{|c|}{$\begin{array}{c}\text { From } \\
\text { Risk-Weight Category }\end{array}$} \\
\hline \multirow{5}{*}{ To } & & $20 \%$ & $\underline{50 \%}$ & $100 \%$ & $\underline{150 \%}$ \\
\hline & $20 \%$ & 0.990 & 0.007 & 0.000 & 0.000 \\
\hline & $50 \%$ & 0.010 & 0.982 & 0.008 & 0.000 \\
\hline & $100 \%$ & 0.000 & 0.011 & 0.986 & 0.020 \\
\hline & $150 \%$ & 0.000 & 0.000 & 0.006 & 0.980 \\
\hline
\end{tabular}




\begin{tabular}{|c|c|c|c|c|c|}
\hline \multicolumn{6}{|c|}{ Table 4: Average Rating Transition Matrix for $85: Q 1-91: Q$} \\
\hline \multicolumn{6}{|c|}{$\begin{array}{c}\text { From } \\
\text { Risk-Weight Category }\end{array}$} \\
\hline \multirow{5}{*}{ To } & & $20 \%$ & $\underline{50 \%}$ & $100 \%$ & $150 \%$ \\
\hline & $20 \%$ & $\overline{0.978}$ & $\overline{0.005}$ & $\overline{0.000}$ & $\overline{0.000}$ \\
\hline & $50 \%$ & 0.020 & 0.974 & 0.005 & 0.001 \\
\hline & $100 \%$ & 0.001 & 0.020 & 0.978 & 0.013 \\
\hline & $150 \%$ & 0.000 & 0.001 & 0.016 & 0.987 \\
\hline
\end{tabular}

\begin{tabular}{|c|c|c|c|c|c|}
\hline \multicolumn{6}{|c|}{ Table 5: Average Rating Transition Matrix for 92:Q1-98:Q } \\
\hline \multicolumn{6}{|c|}{$\begin{array}{c}\text { From } \\
\text { Risk-Weight Category }\end{array}$} \\
\hline \multirow{5}{*}{ To } & & $20 \%$ & $50 \%$ & $\underline{100 \%}$ & $\underline{150 \%}$ \\
\hline & $20 \%$ & $\overline{0.979}$ & $\overline{0.003}$ & $\overline{0.000}$ & $\overline{0.000}$ \\
\hline & $50 \%$ & 0.021 & 0.984 & 0.006 & 0.000 \\
\hline & $100 \%$ & 0.000 & 0.013 & 0.985 & 0.019 \\
\hline & $150 \%$ & 0.000 & 0.000 & 0.009 & 0.981 \\
\hline
\end{tabular}

Table 6: Average Rating Transition Matrix for 99:Q1-00:Q4

\section{From}

Risk-Weight Category

$\begin{array}{rrrrrr}\text { To } & & \underline{20 \%} & \underline{50 \%} & \underline{100 \%} & \underline{150 \%} \\ & 20 \% & 0.982 & 0.010 & 0.000 & 0.000 \\ & 50 \% & 0.018 & 0.972 & 0.010 & 0.001 \\ 100 \% & 0.000 & 0.017 & 0.960 & 0.008 \\ 150 \% & 0.000 & 0.001 & 0.030 & 0.991\end{array}$




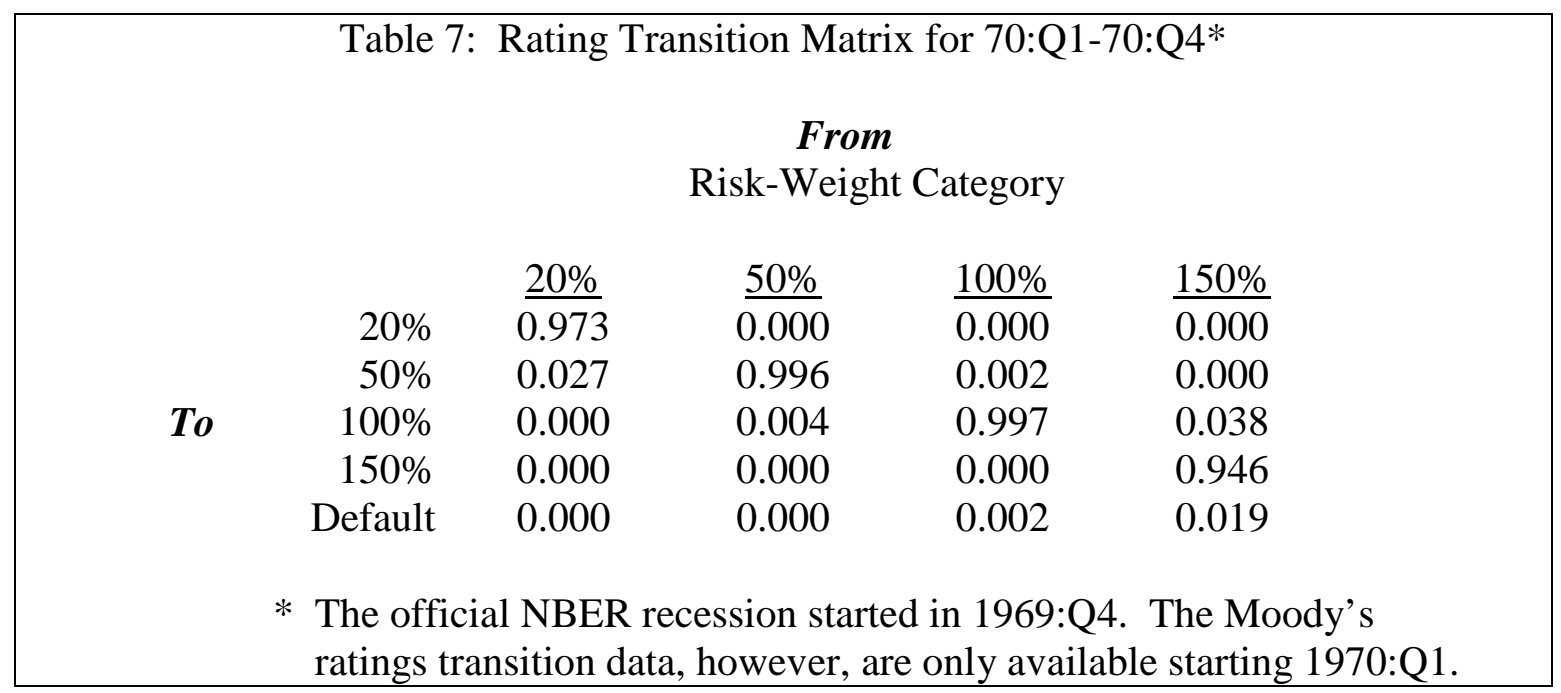

\begin{tabular}{|c|c|c|c|c|c|}
\hline \multicolumn{6}{|c|}{ Table 8: Rating Transition Matrix for 73:Q4-75:Q1 } \\
\hline & \multicolumn{5}{|c|}{$\begin{array}{c}\text { From } \\
\text { Risk-Weight Category }\end{array}$} \\
\hline \multirow{6}{*}{ To } & & $20 \%$ & $50 \%$ & $100 \%$ & $150 \%$ \\
\hline & $20 \%$ & 1.000 & 0.007 & 0.000 & 0.000 \\
\hline & $50 \%$ & 0.000 & 0.980 & 0.000 & 0.000 \\
\hline & $100 \%$ & 0.000 & 0.014 & 0.994 & 0.000 \\
\hline & $150 \%$ & 0.000 & 0.000 & 0.005 & 0.964 \\
\hline & Default & 0.000 & 0.000 & 0.002 & 0.036 \\
\hline
\end{tabular}

\begin{tabular}{|c|c|c|c|c|c|}
\hline \multicolumn{6}{|c|}{$\begin{array}{l}\text { From } \\
\text { Risk-Weight Category }\end{array}$} \\
\hline \multirow{6}{*}{ To } & & $20 \%$ & $\underline{50 \%}$ & $100 \%$ & $150 \%$ \\
\hline & $20 \%$ & 0.993 & 0.003 & 0.000 & 0.000 \\
\hline & $50 \%$ & 0.007 & 0.994 & 0.002 & 0.000 \\
\hline & $100 \%$ & 0.000 & 0.003 & 0.991 & 0.000 \\
\hline & $150 \%$ & 0.000 & 0.000 & 0.008 & 0.976 \\
\hline & Default & 0.000 & 0.000 & 0.000 & 0.024 \\
\hline & $\begin{array}{l}\text { tudy, w } \\
\text { nn. }\end{array}$ & ted & per & 1980 & $1982: Q 2$ as a single \\
\hline
\end{tabular}




\begin{tabular}{|c|c|c|c|c|c|}
\hline \multicolumn{6}{|c|}{ Table 10: Rating Transition Matrix for 90:Q3-91:Q1 } \\
\hline & \multicolumn{5}{|c|}{$\begin{array}{c}\text { From } \\
\text { Risk-Weight Category }\end{array}$} \\
\hline \multirow{6}{*}{ To } & & $20 \%$ & $50 \%$ & $100 \%$ & $150 \%$ \\
\hline & $20 \%$ & $\overline{0.980}$ & $\overline{0.000}$ & $\overline{0.000}$ & $\overline{0.000}$ \\
\hline & $50 \%$ & 0.021 & 0.980 & 0.002 & 0.000 \\
\hline & $100 \%$ & 0.000 & 0.002 & 0.971 & 0.019 \\
\hline & $150 \%$ & 0.000 & 0.000 & 0.023 & 0.916 \\
\hline & Default & 0.000 & 0.000 & 0.005 & 0.065 \\
\hline
\end{tabular}

Table 11: Percent Change in Risk-Weighted Loans (STBL)

\begin{tabular}{|c|c|c|c|c|}
\hline & \multicolumn{4}{|c|}{ NBER Recession } \\
\hline & 70:Q1-70:Q4* & 73:Q4-75:Q1 & $\underline{80: Q 1-82: Q 3}{ }^{* *}$ & 90:Q3-91:Q1 \\
\hline All Banks & $-0.3 \%$ & $+0.3 \%$ & $+0.2 \%$ & $+0.7 \%$ \\
\hline Large Banks & $-0.2 \%$ & $+0.3 \%$ & $+0.2 \%$ & $+0.9 \%$ \\
\hline Small Banks & $-0.4 \%$ & $+0.3 \%$ & $+0.2 \%$ & $+0.6 \%$ \\
\hline Foreign Banks & $-0.6 \%$ & $+0.2 \%$ & $+0.1 \%$ & $+0.4 \%$ \\
\hline
\end{tabular}

* The official NBER recession started in 1969:Q4. The Moody's ratings transition data, however, are only available starting 1970:Q1.

** In our study, we treated the entire period from 1980:Q1 to 1982:Q2 as a single recession. 
Nonfinancial Corporate Borrowers with Moody's Rated Senior Unsecured Debt

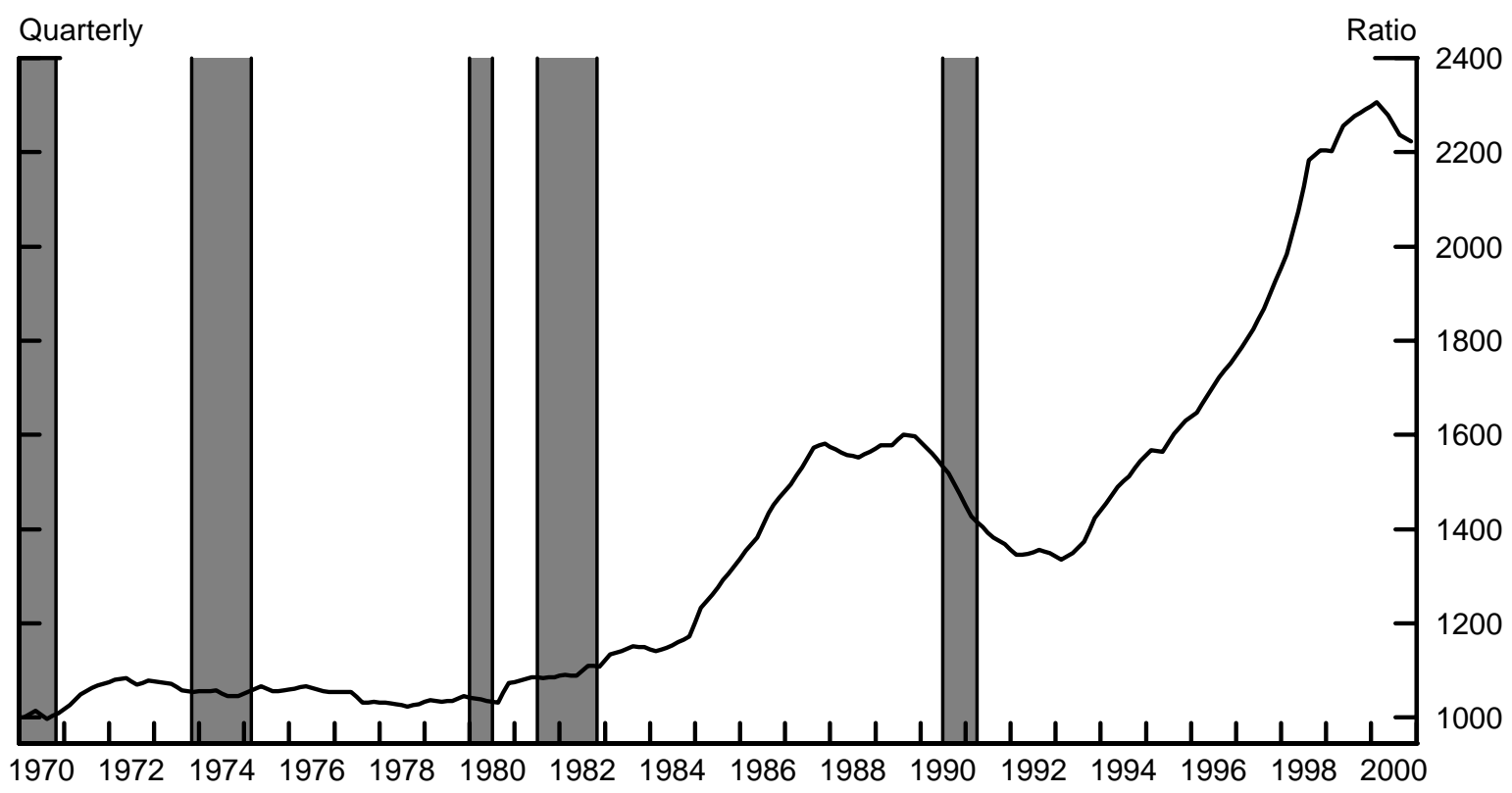

Shares of Rated Nonfinancial Corporate Borrowers by Risk Category

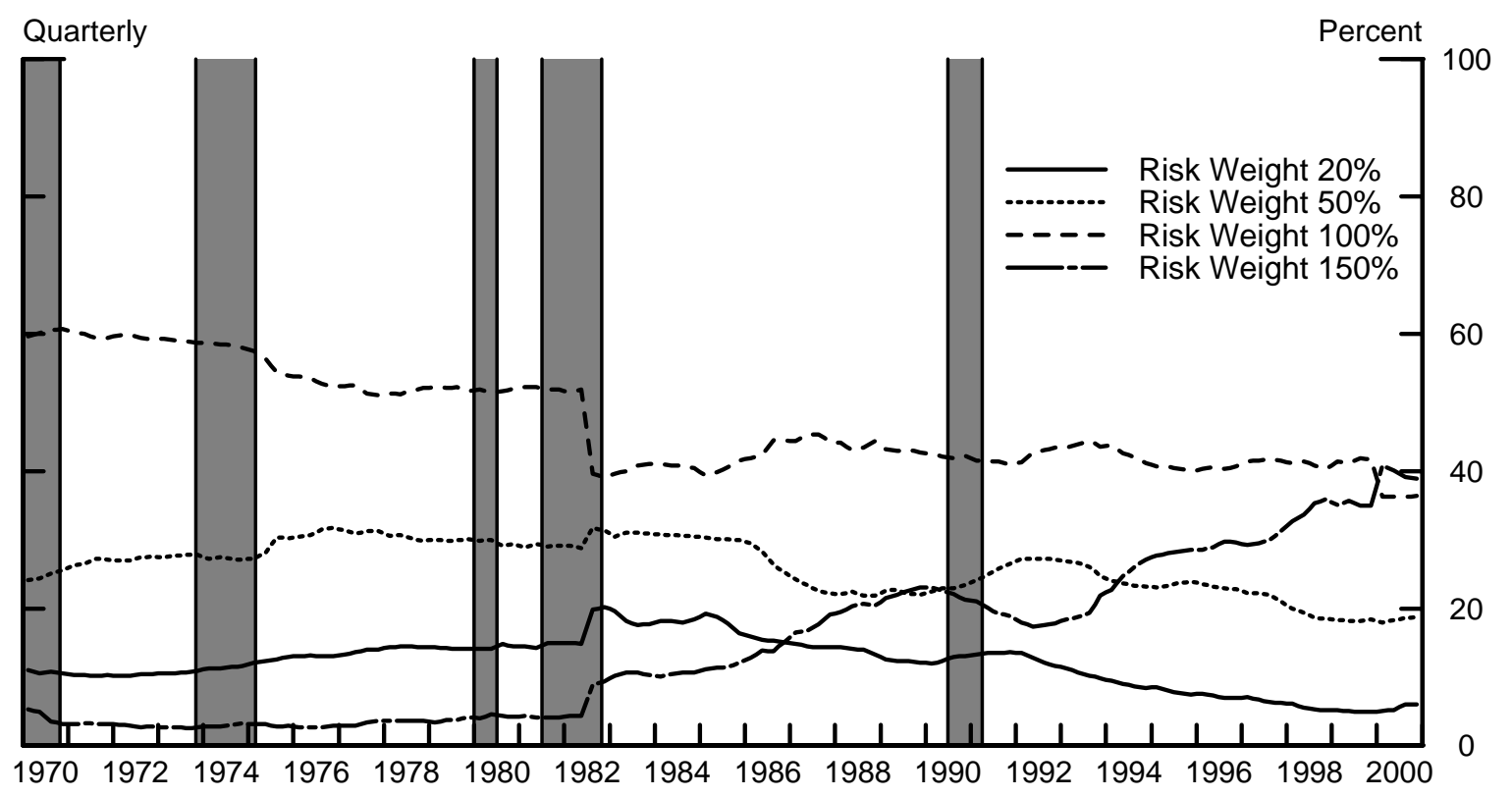




\section{Estimated Risk Premiums on C\&I Loans}

All Banks (STBL)

Quarterly

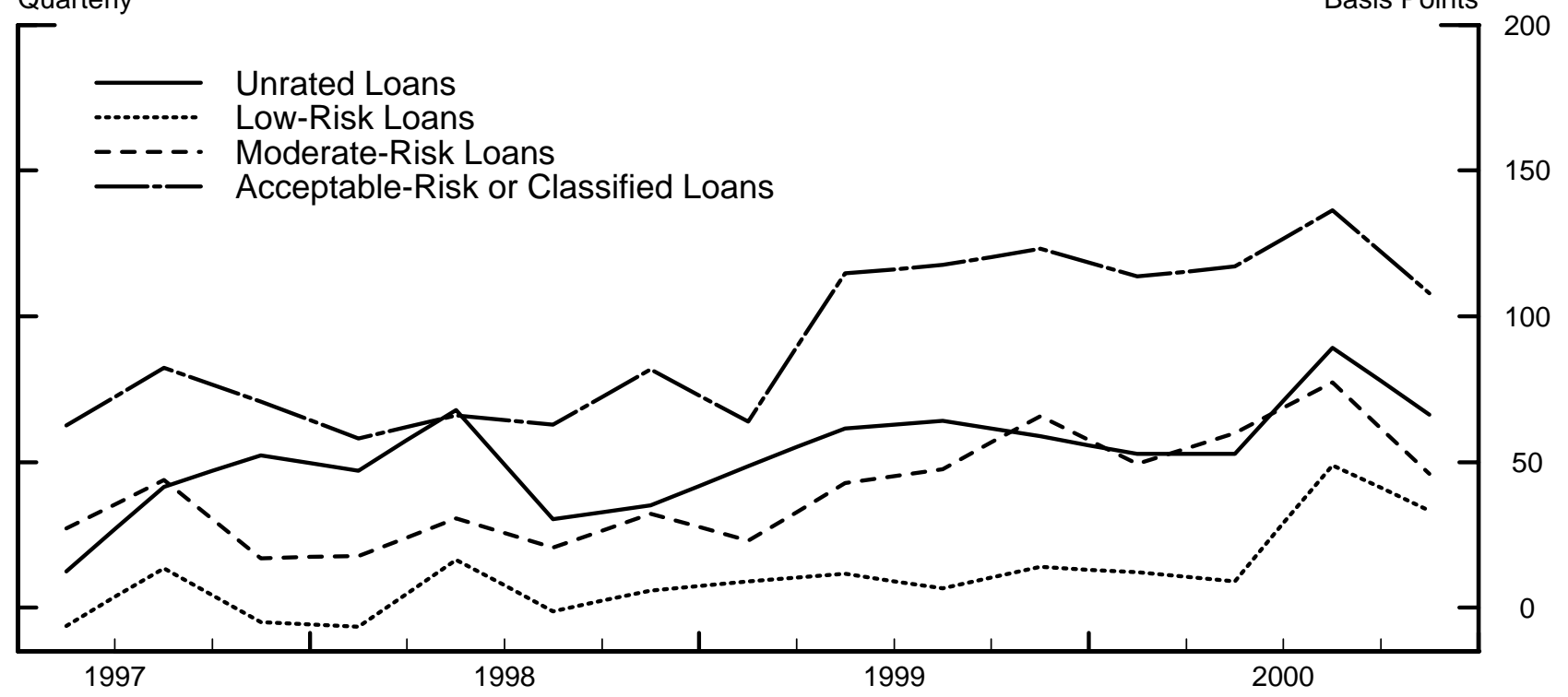

NOTE: The estimated risk premiums are measured relative to minimal risk loans. 
Shares of C\&I Loans Outstanding by Risk Rating (STBL)

All Banks

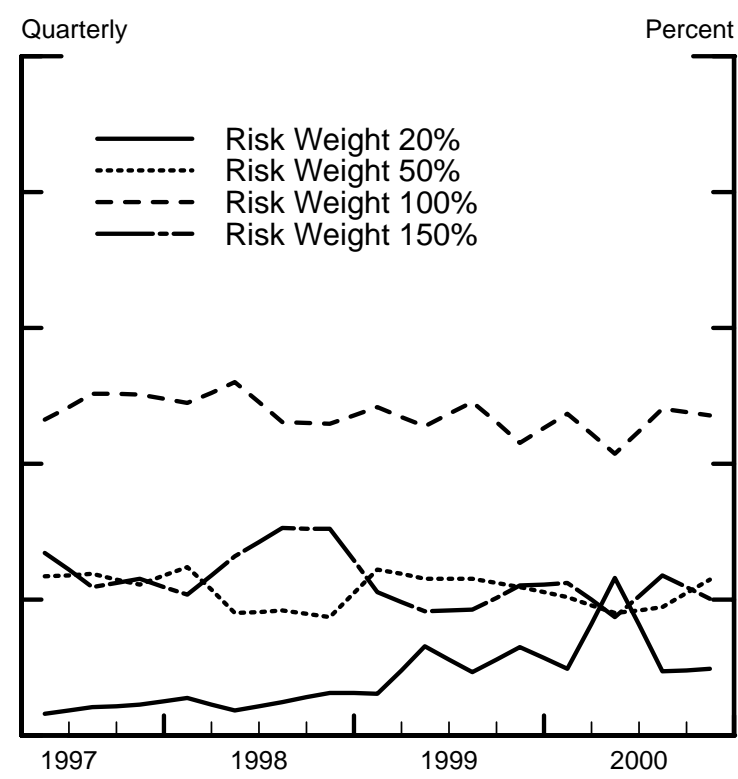

Small Domestic Banks

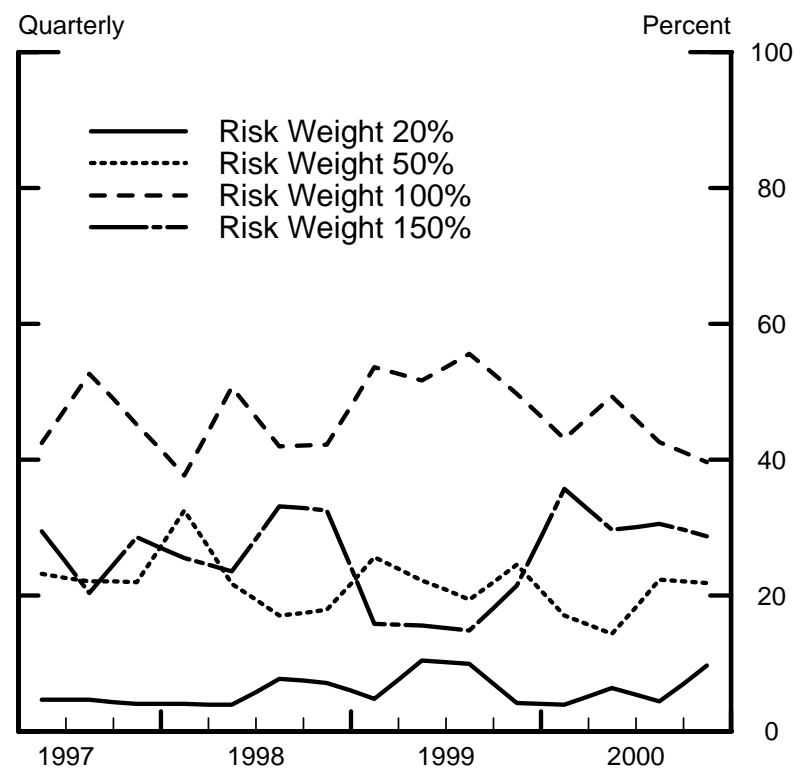

Large Domestic Banks

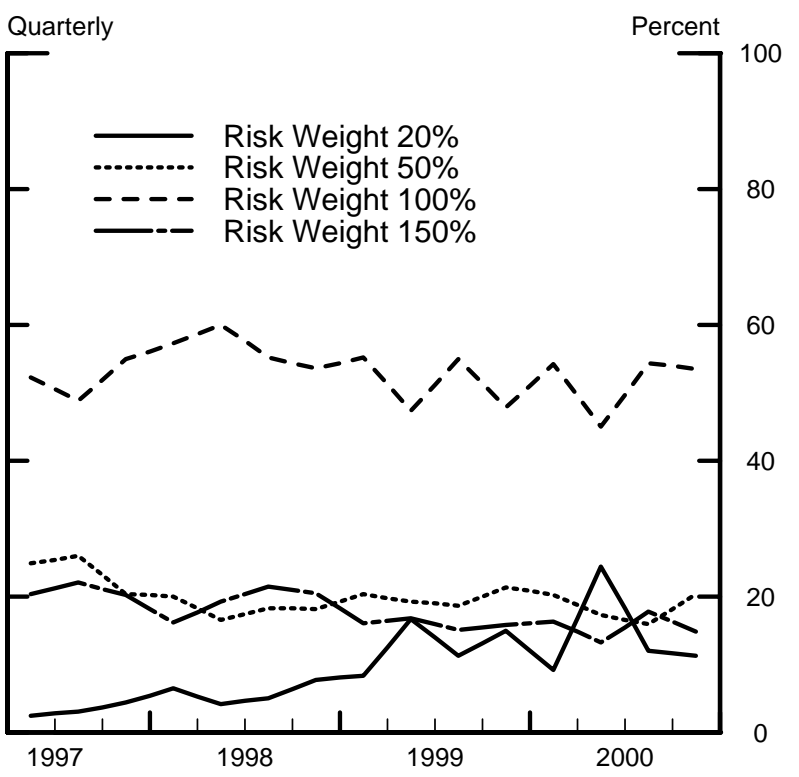

Foreign Banks

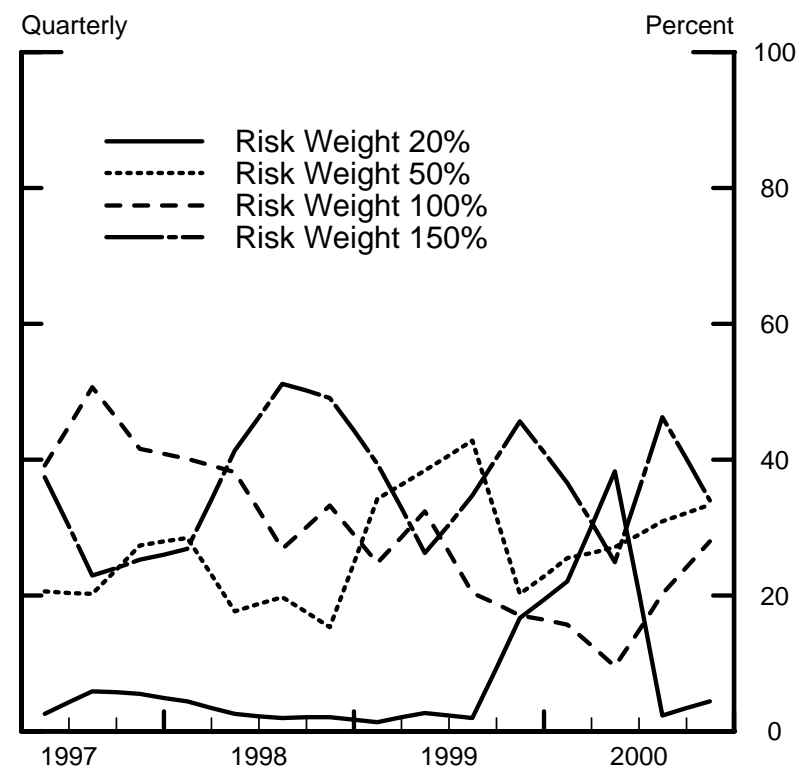


Required Capital (STBL)

All Banks

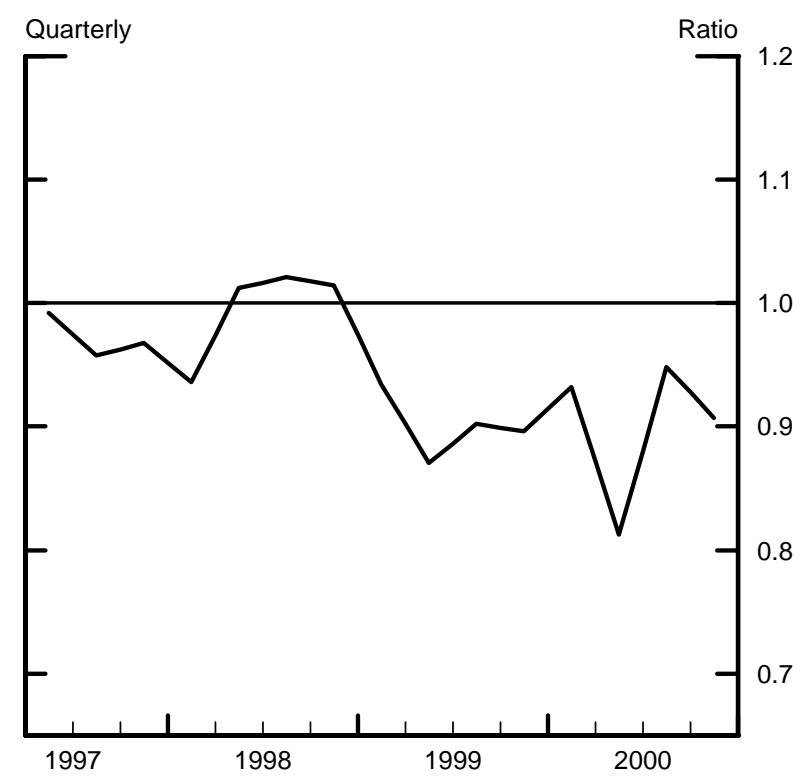

Small Domestic Banks

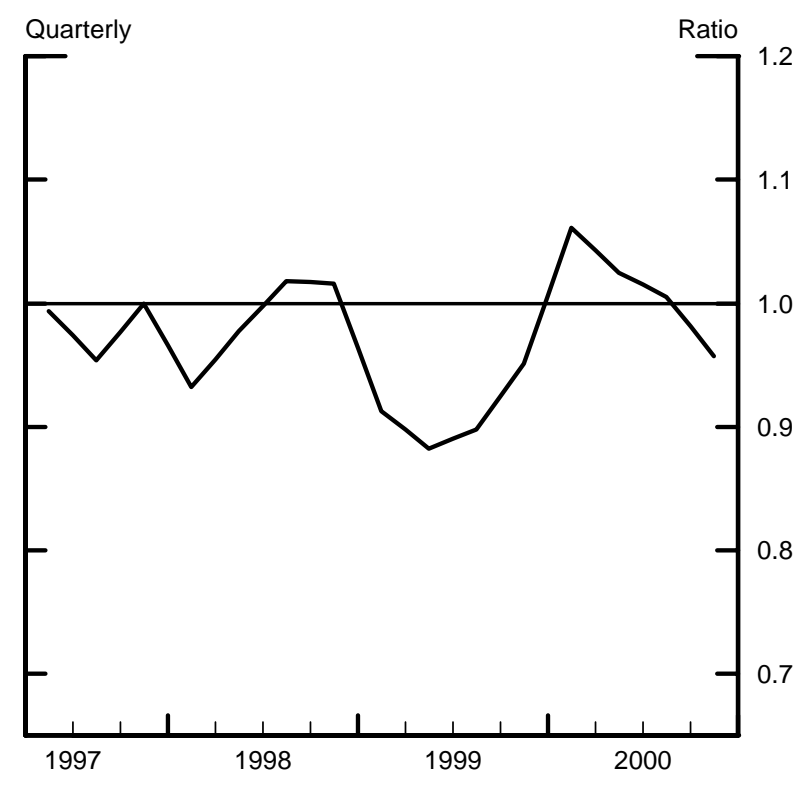

Large Domestic Banks

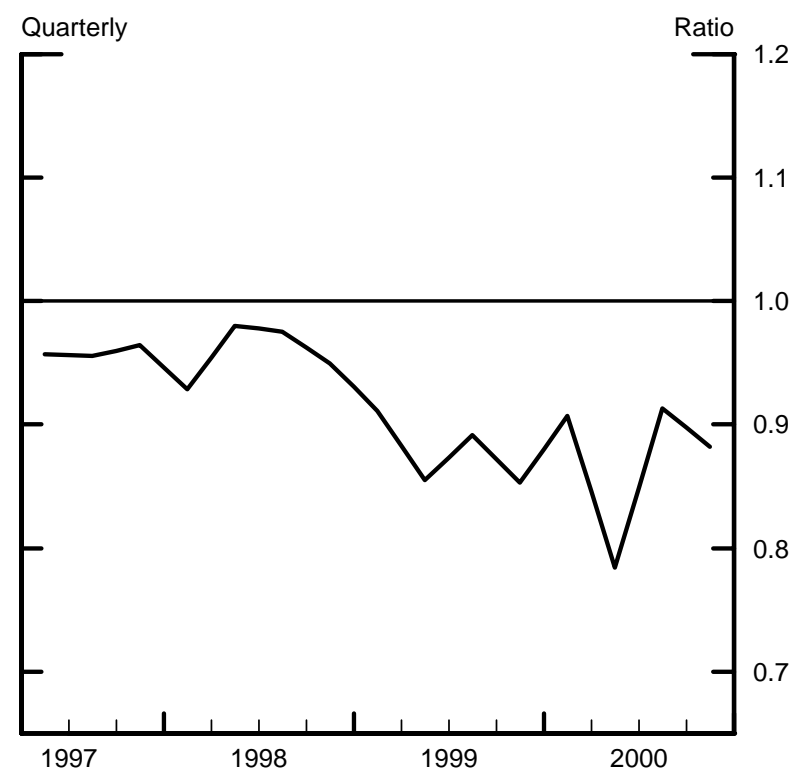

Foreign Banks

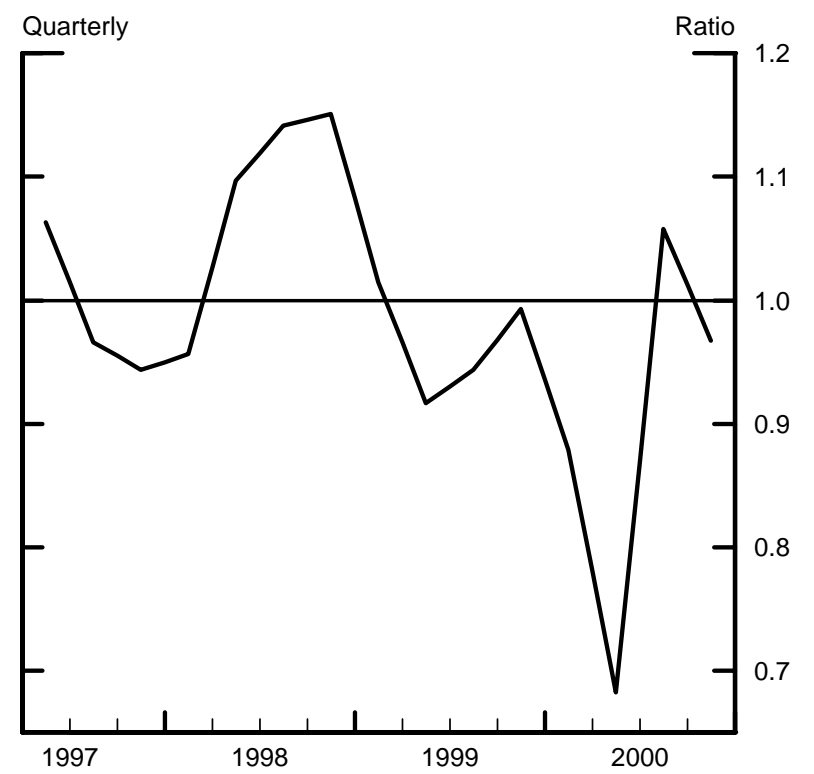




\section{Average Risk Distribution of C\&I Loans Outstanding}
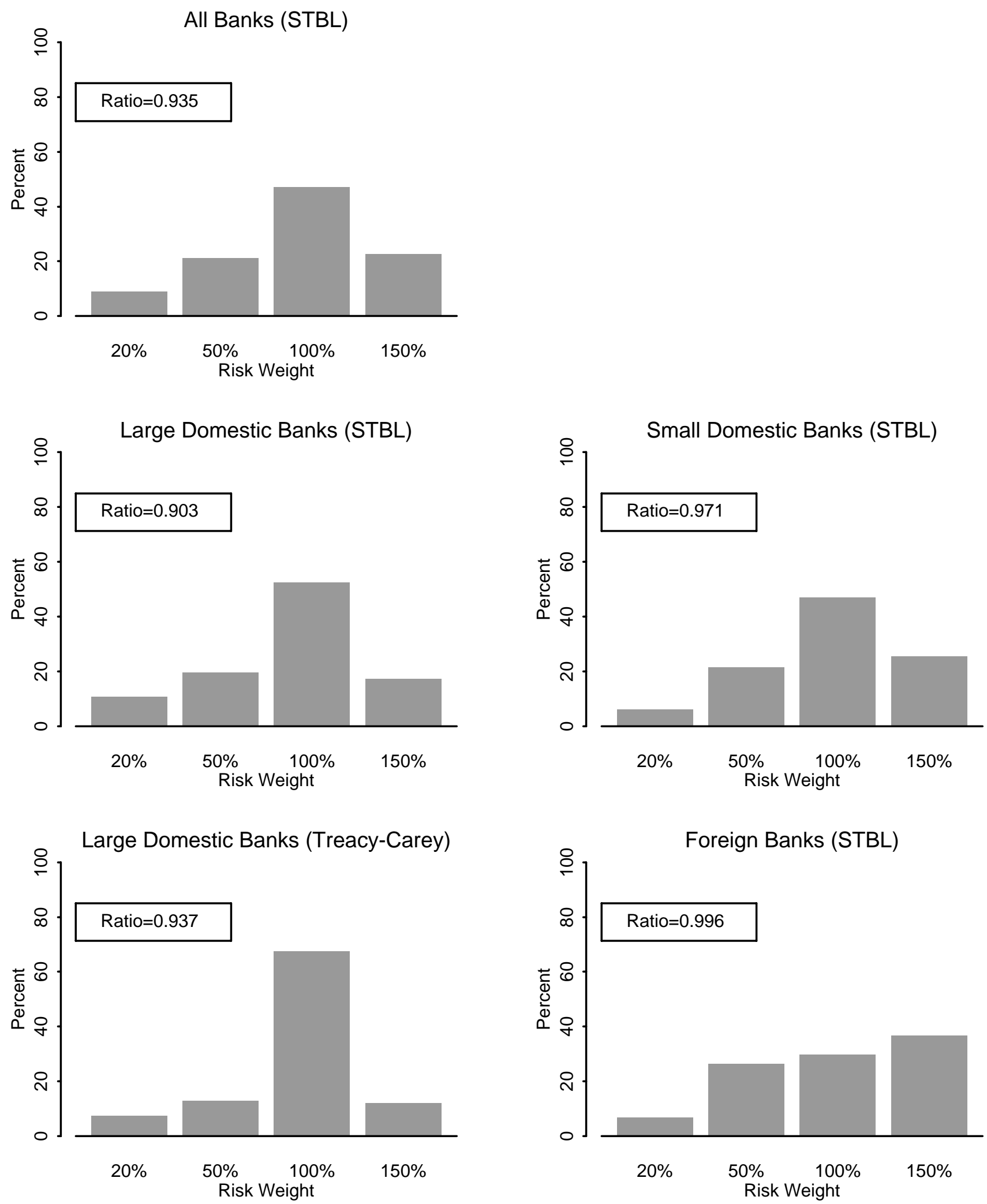
Regulatory Capital and Share of Industry Assets at Well-Capitalized Banks

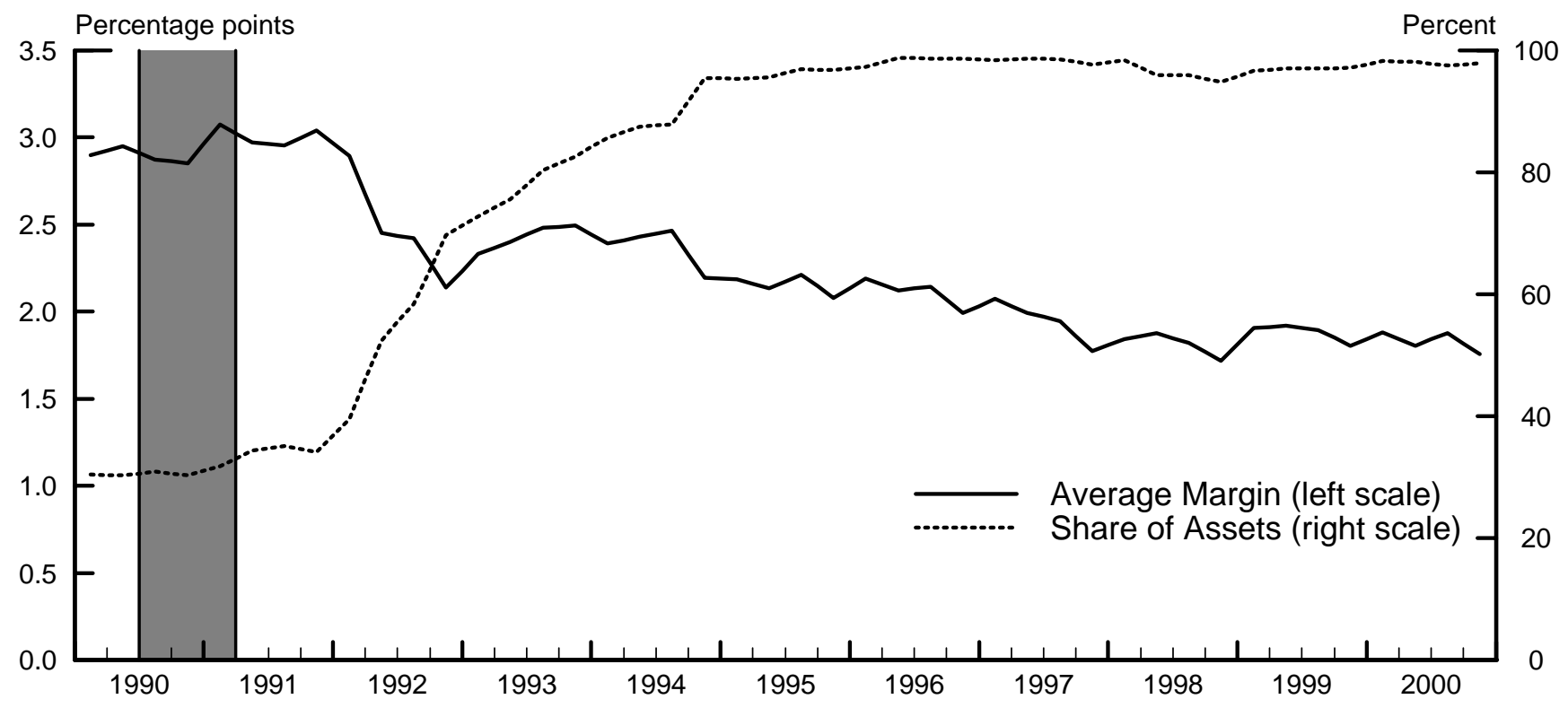


Counterfactual Required Capital

All Banks (STBL)

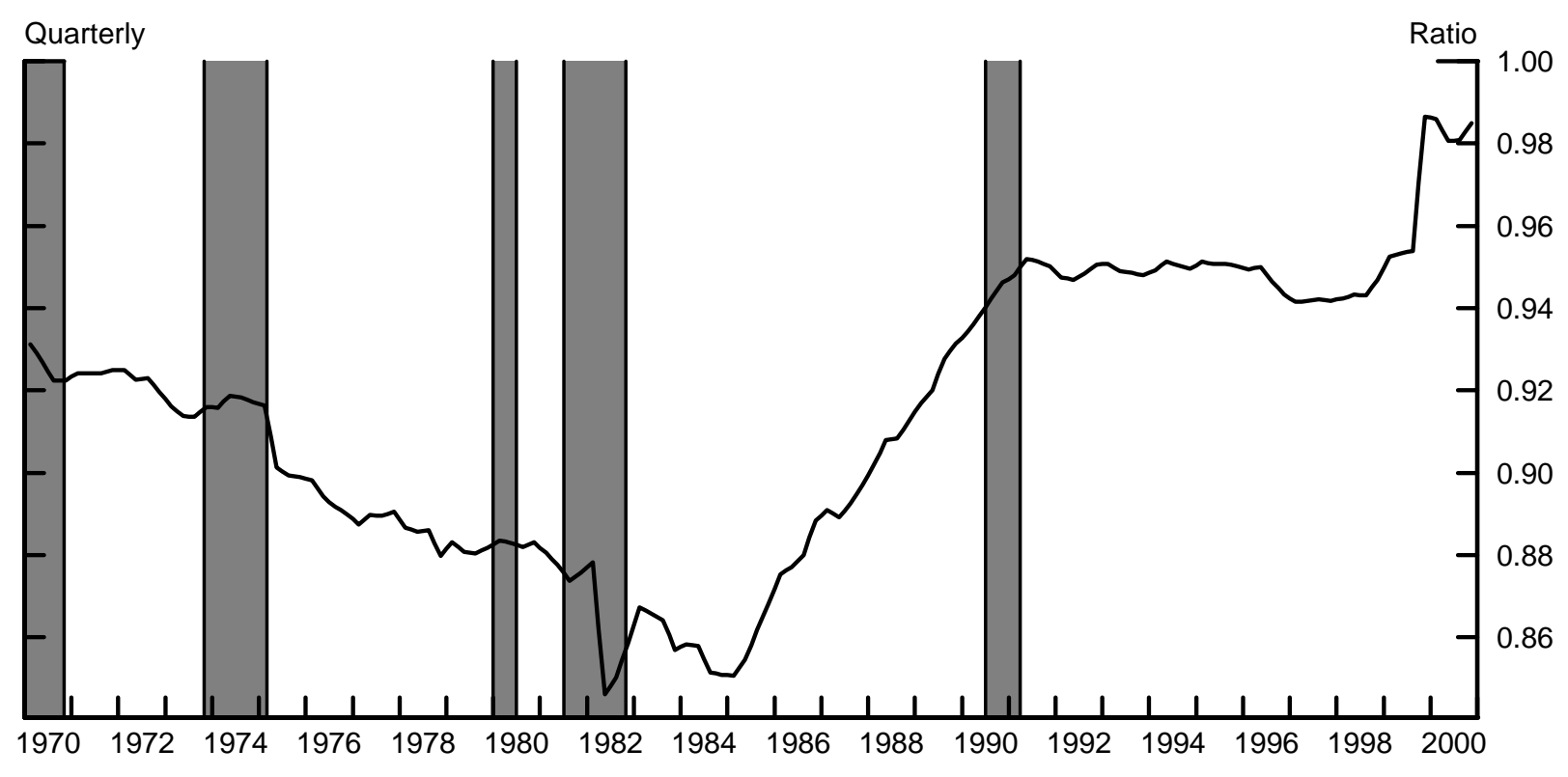


Counterfactual Required Capital

\section{Treacy-Carey (1988) Sample}

(26 Large Domestic BHCs)

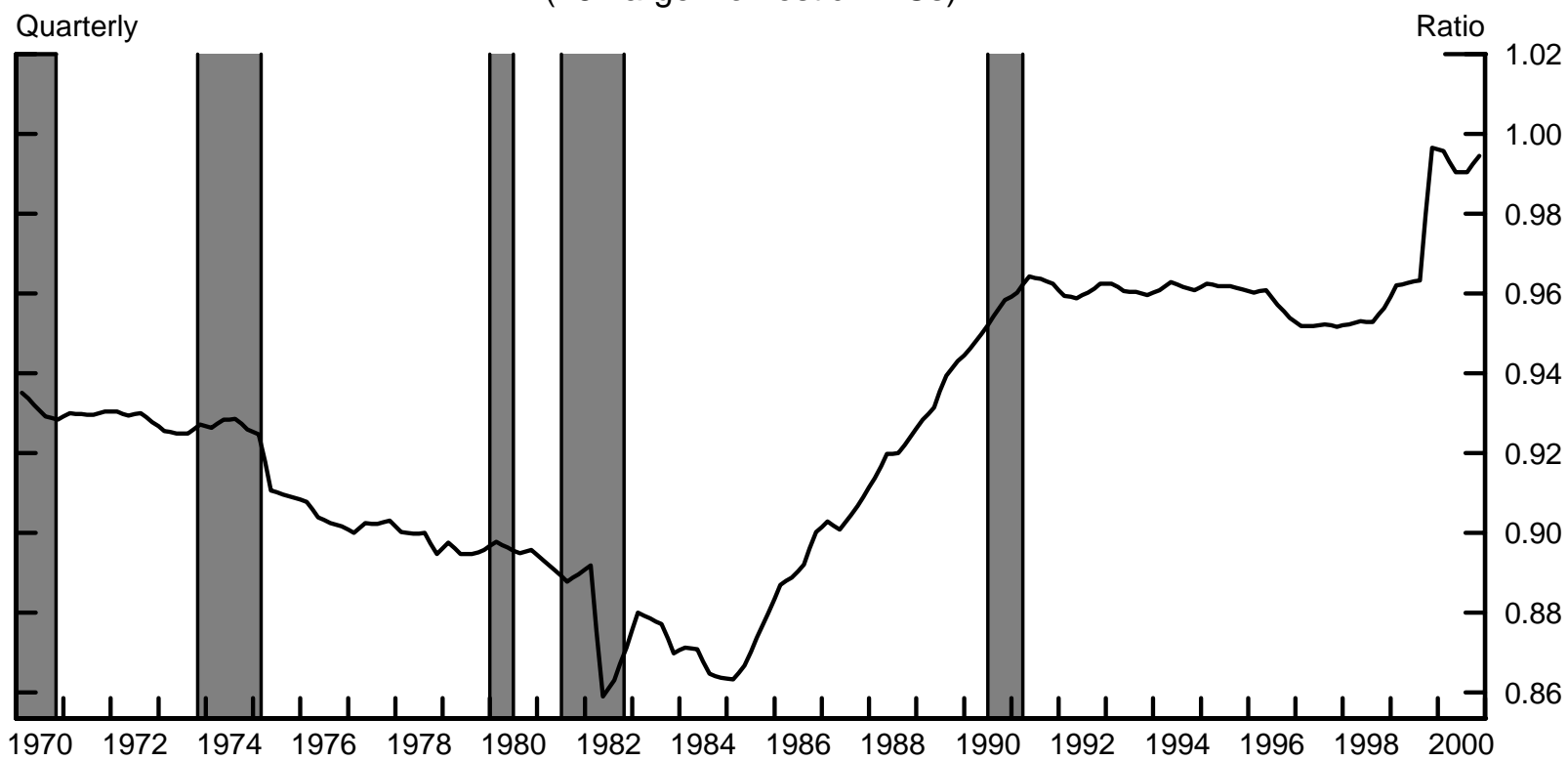

\section{Moody's Rated Borrowers}

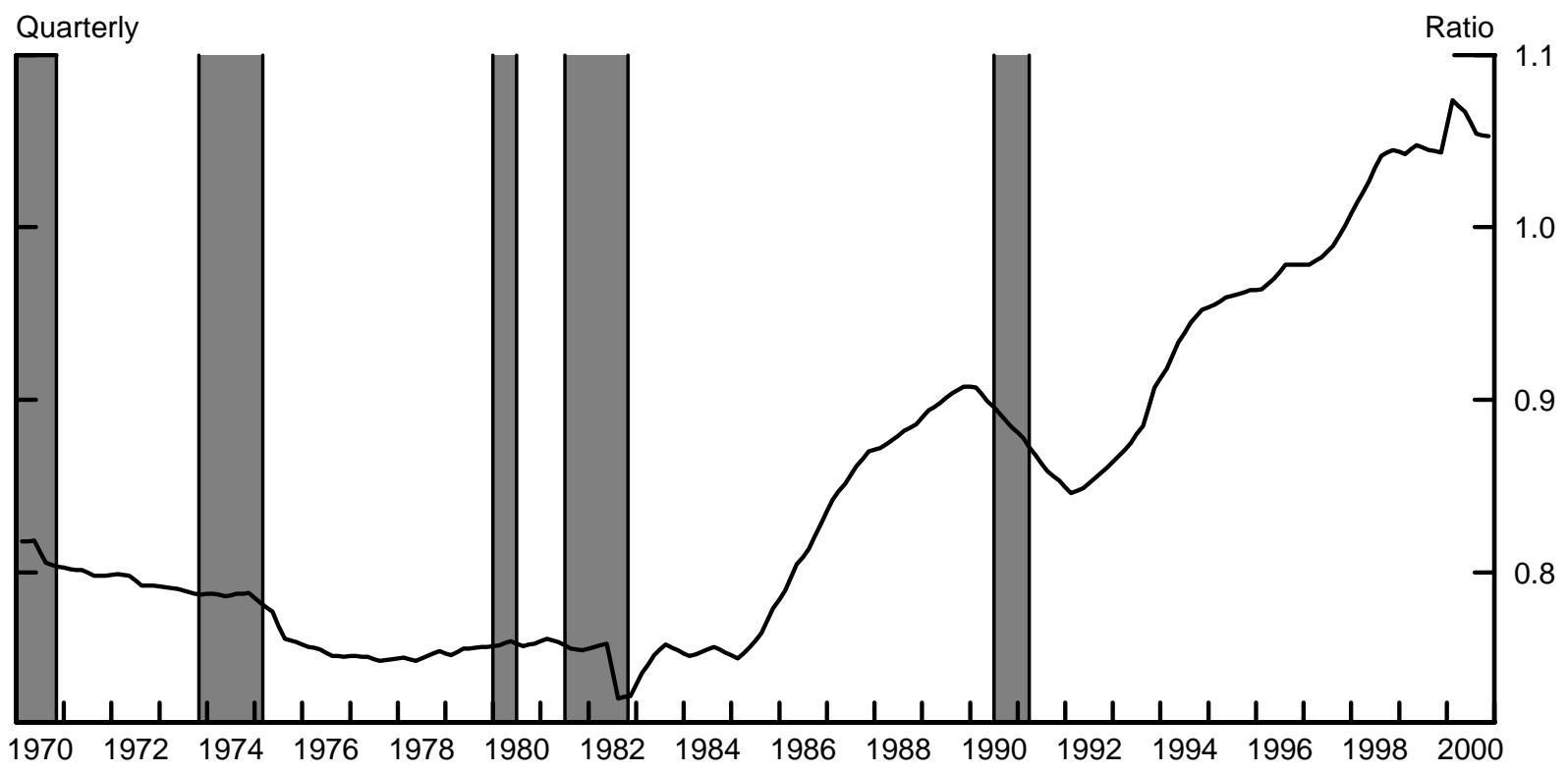


Exhibit 9

All Banks (STBL)

\section{Counterfactual Required Capital}

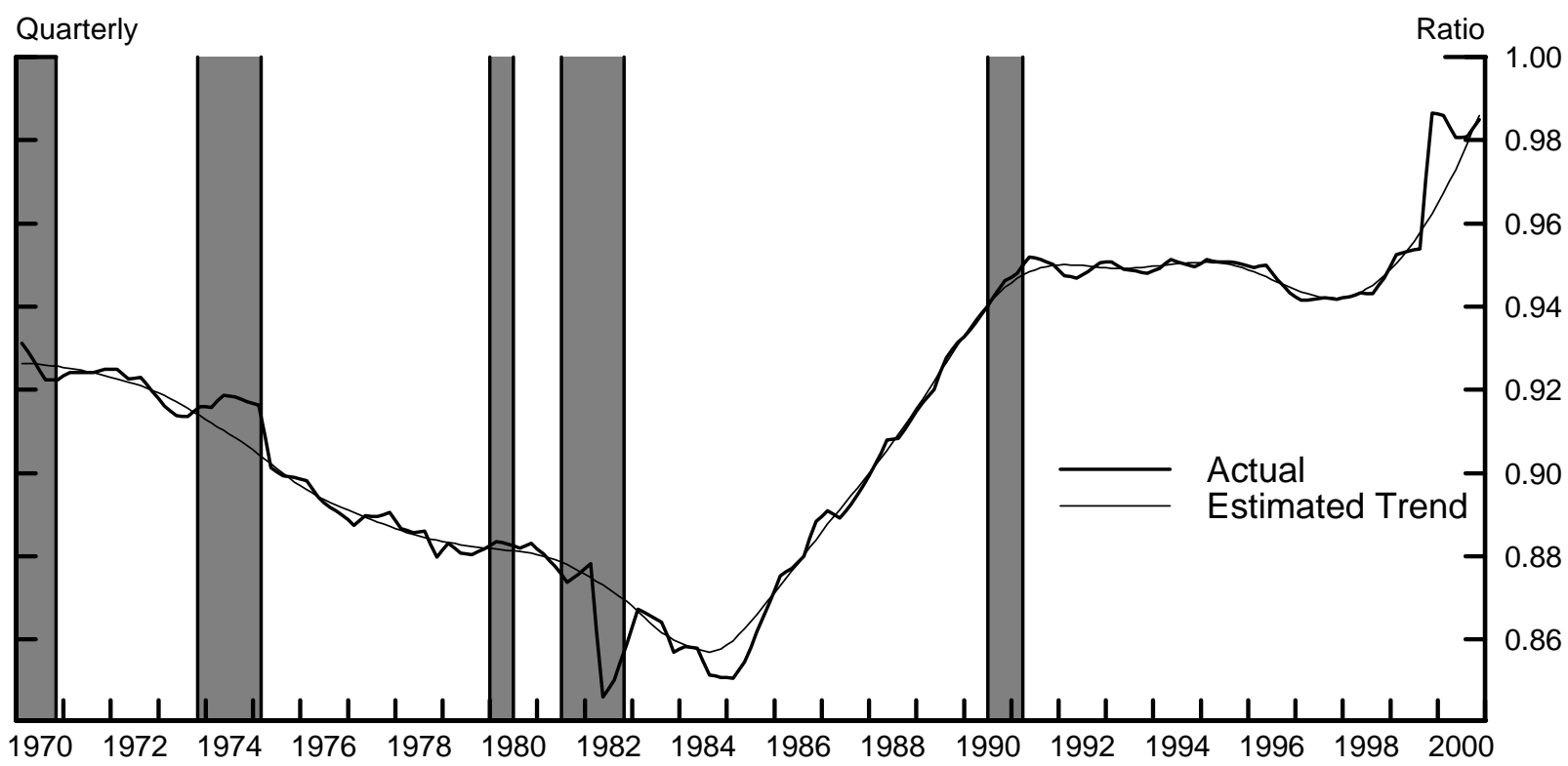

Recession-Specific Regulatory Capital Deviations

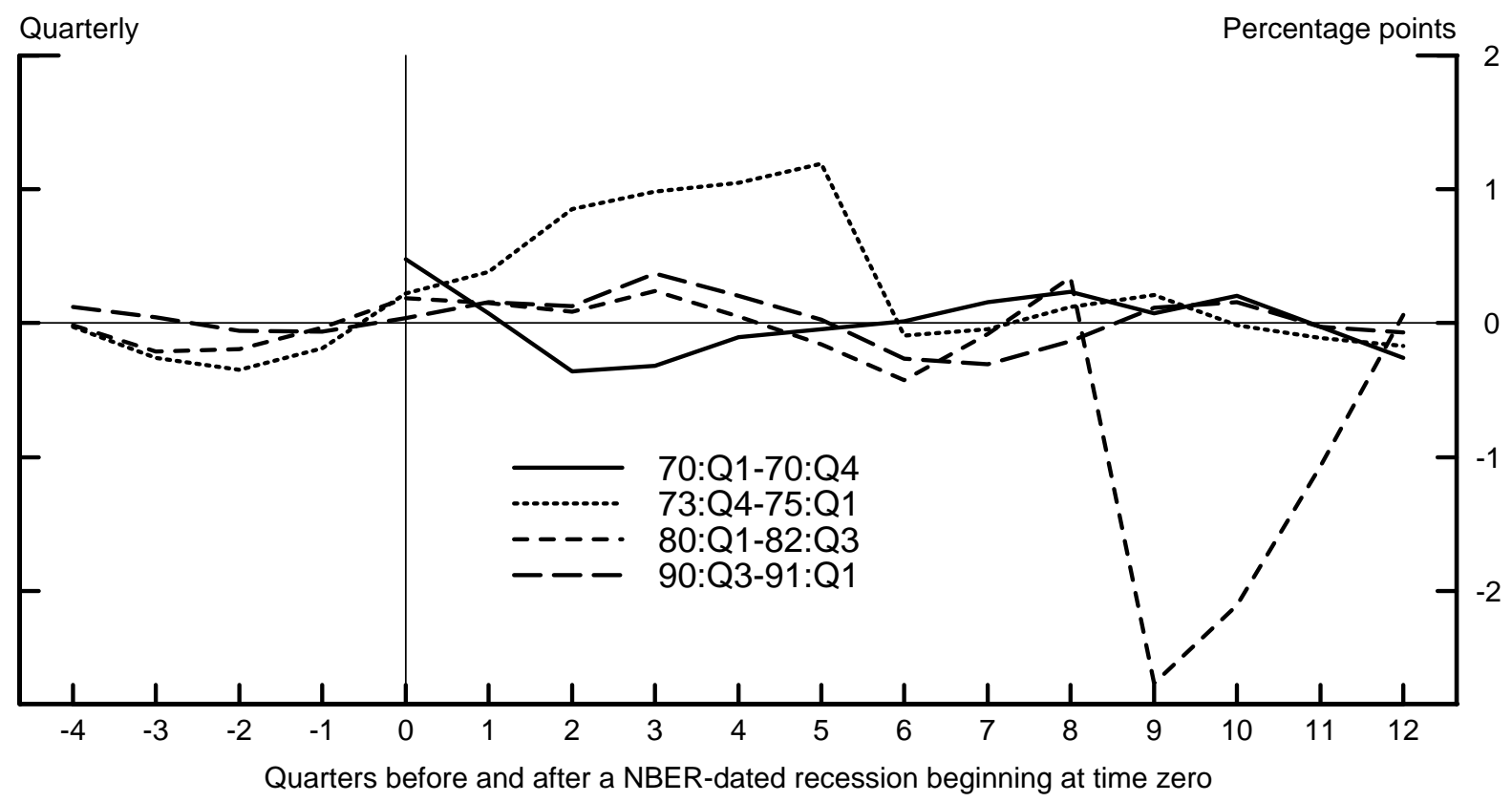

